\title{
Glutamate Receptor Trafficking and Protein Synthesis Mediate the Facilitation of LTP by Secreted Amyloid Precursor Protein-Alpha
}

\author{
Bruce G. Mockett, ${ }^{1}$ Diane Guévremont, ${ }^{2}$ Megan K. Elder, ${ }^{2}$ Karen D. Parfitt, ${ }^{4}$ Katie Peppercorn, ${ }^{3}$ Jodi Morrissey, ${ }^{1}$ \\ Anurag Singh, ${ }^{1}$ Timothy J. Hintz, ${ }^{1}$ Lisa Kochen, ${ }^{5}$ Susanne tom Dieck, ${ }^{5}$ Erin Schuman, ${ }^{5}$ Warren P. Tate, ${ }^{3}$ \\ Joanna M. Williams, ${ }^{2}$ and ${ }^{\circ}$ Wickliffe C. Abraham ${ }^{1}$ \\ ${ }^{1}$ Department of Psychology, ${ }^{2}$ Department of Anatomy, ${ }^{3}$ Department of Biochemistry, Brain Health Research Centre, Brain Research New Zealand, \\ University of Otago, Dunedin 9054, New Zealand, ${ }^{4}$ Department of Neuroscience, Pomona College, Claremont, California 91711, and ${ }^{5}$ Max Planck Institute \\ for Brain Research, 60438 Frankfurt am Main, Germany
}

Secreted amyloid precursor protein-alpha $(\operatorname{sAPP} \alpha)$ has growth factor-like properties and can modulate long-term potentiation (LTP) and memory. Here, we demonstrate that exposure to sAPP $\alpha$ converts short-lasting LTP into protein-synthesis-dependent late LTP in hippocampal slices from male rats. sAPP $\beta$ had no discernable effect. We hypothesized that sAPP $\alpha$ facilitated LTP via regulated glutamate receptor trafficking and de novo protein synthesis. We found using a linear mixed model that sAPP $\alpha$ stimulated trafficking of GluA2lacking AMPARs, as well as NMDARs to the extrasynaptic cell surface, in a calcium/calmodulin-dependent kinase II and protein kinase G-dependent manner. Both cell surface receptor accumulation and LTP facilitation were present even after sAPP $\alpha$ washout and inhibition of receptor trafficking or protein synthesis prevented all these effects. Direct visualization of newly synthesized proteins (FUNCAT-PLA) confirmed the ability of sAPP $\alpha$ to stimulate de novo protein synthesis and revealed GluA1 as one of the upregulated proteins. Therefore, sAPP $\alpha$ generates a coordinated synthesis and trafficking of glutamate receptors to the cell surface that facilitate LTP.

Key words: glutamate receptor trafficking; hippocampus; metaplasticity; protein synthesis; secreted amyloid precursor protein-alpha; synaptic plasticity

Significance Statement

Secreted amyloid precursor protein-alpha $(\operatorname{sAPP} \alpha)$ is a neurotrophic and neuroprotective protein that can promote synaptic plasticity and memory, yet the molecular mechanisms underlying these effects are still not well understood. Here, we show that sAPP $\alpha$ facilitates long-term potentiation (LTP) in a concentration-dependent fashion through cellular processes involving de novo protein synthesis and trafficking of both GluA2-lacking AMPARs and NMDARs to the extrasynaptic cell surface. sAPP $\alpha$ also enhances GluA1, but not GluA2, synthesis. The trafficking effects, along with the LTP facilitation, persist after sAPP $\alpha$ washout, revealing a metaplastic capability of exogenous sAPP $\alpha$ administration. sAPP $\alpha$ thus facilitates LTP through coordinated activation of protein synthesis and trafficking of glutamate receptors to the cell surface, where they are positioned for priming LTP.

\section{Introduction}

Alzheimer's disease $(\mathrm{AD})$ and other neuropathologies are characterized by the accumulation of the peptide amyloid- $\beta(\mathrm{A} \beta)$,

Received July 17, 2018; revised Jan. 15, 2019; accepted Feb. 11, 2019.

Author contributions: B.G.M., M.K.E., K.D.P., J.M., S.t.D., E.S., W.P.T., J.M.W., and W.C.A. designed research; B.G.M., D.G., M.K.E., K.D.P., K.P., J.M., A.S., T.J.H., and L.K. performed research;B.G.M., D.G., M.K.E., K.D.P., J.M., A.S., T.J.H., S.t.D., E.S., W.P.T., J.M.W., and W.C.A. analyzed data; B.G.M., D.G., M.K.E., K.P., W.P.T., J.M.W., and W.C.A. wrote the first draft of the paper; B.G.M., D.G., M.K.E., K.D.P., J.M., A.S., E.S., W.P.T., J.M.W., and W.C.A. edited the paper; B.G.M. and W.C.A. wrote the paper.

This work was supported by the Health Research Council of New Zealand (W.C.A, B.G.M, W.P.T., and J.M.W.), the German Academic Exchange Service (M.E.), the University of Otago (postgraduate scholarships to M.K.E, J.M., and A.S.), the Max Planck Society (E.M.S. and S.t.D.), the European Research Council (E.M.S. and S.t.D.), and the Cluster which is generated by $\beta$ - and $\gamma$-secretase cleavage of amyloid precursor protein (APP). Interestingly, alternative cleavage of APP within the A $\beta$ sequence by ADAM-10 (a disintegrin and metalloprotease-10, also known as $\alpha$-secretase) leads to the release of the neurotrophic and neuroprotective protein secreted APP-alpha $(\operatorname{sAPP} \alpha)$. This protein exhibits a number of physio-

\footnotetext{
of Excellence for Macromolecular Complexes (E.M.S. and S.t.D.). We thank S. Hulme and S. Ohline for help with experiments and A. Gray for biostatistical support.

The authors declare no competing financial interests.

Correspondence should be addressed to Wickliffe C. Abraham at cabraham@psy.otago.ac.nz.

https://doi.org/10.1523/JNEUROSCl.1826-18.2019

Copyright $\odot 2019$ the authors
} 
logical, biochemical, and behavioral effects that have the potential to mitigate the detrimental effects of $\mathrm{A} \beta$ (for review, see Mockett et al., 2017), including enhanced synaptogenesis and dendrite growth (Chasseigneaux et al., 2011; Baratchi et al., 2012; Fol et al., 2016), protection against neurotoxicity (Mattson et al., 1993; Copanaki et al., 2010; Ryan et al., 2013), facilitated hippocampal long-term potentiation (LTP) (Ishida et al., 1997; Taylor et al., 2008; Hick et al., 2015), and facilitated memory function (Roch et al., 1994; Meziane et al., 1998). This latter feature is conserved across mammalian (Meziane et al., 1998), avian (Mileusnic et al., 2004), and invertebrate (Bourdet et al., 2015) species. Furthermore, sAPP $\alpha$ rescues LTP and memory impairments in Alzheimer's mouse models (Fol et al., 2016; Tan et al., 2018), in mouse knock-outs of APP expression, or with $\alpha$-secretase inhibition (Ring et al., 2007; Taylor et al., 2008; Hick et al., 2015; Moreno et al., 2015; Fol et al., 2016; Richter et al., 2018). Together, these data indicate that $\mathrm{APP} \alpha$ plays a critical role in LTP, but the molecular mechanisms engaged by $\operatorname{sAPP} \alpha$ to regulate LTP are not yet understood.

Early studies reported that $\operatorname{sAP} \alpha$ reduced intracellular calcium, reduced NMDAR-mediated currents and enhanced potassium currents in cultured cells (Furukawa et al., 1996; Furukawa and Mattson, 1998), but these effects have been hard to reconcile with an enhancement of LTP and memory. In contrast, we have shown in acute hippocampal slices that exogenously applied recombinant human SAPP $\alpha$ caused a mild enhancement of tetanically induced NMDAR-mediated synaptic currents (Taylor et al., 2008) while having no effect on basal AMPAR-mediated or NMDAR-mediated synaptic transmission. The fact that sAPP $\alpha$ did not affect basal synaptic transmission led us to investigate other mechanisms by which sAPP $\alpha$ might facilitate LTP.

LTP is generated following NMDAR activation and subsequent activation of key kinases such as calcium/calmodulin-dependent kinase II (CaMKII). Initially, it is expressed predominantly by posttranslational events including AMPAR trafficking to the synapses, especially GluA2-lacking AMPARs (Shi et al., 1999; Plant et al., 2006). With sufficient stimulation, this early phase is followed by later phases requiring de novo synaptic protein synthesis (Krug et al., 1984; Otani et al., 1989) and transcription (Nguyen et al., 1994; Frey et al., 1996) to stabilize LTP into its long-lasting forms. Previously, we have shown that recombinant sAPP $\alpha$ can stimulate protein synthesis in synaptoneurosomes isolated from adult rat hippocampi, an effect mediated by activation of protein kinase G (PKG), CaMKII, and extracellular signal related kinase (ERK) (Claasen et al., 2009). It is notable, however, that $\operatorname{SAP} \alpha$ can faciliate LTP from the point of its initial induction (Taylor et al., 2008; Hick et al., 2015), suggesting that mechanisms other than protein synthesis may also be engaged by $\operatorname{sAPP} \alpha$. Here, we hypothesized that $\operatorname{sAPP} \alpha$ enhances AMPAR trafficking while also upregulating de novo protein synthesis. We found that $\operatorname{sAPP} \alpha$ indeed stimulated a coordinated glutamate receptor trafficking and protein synthesis response to facilitate hippocampal LTP. These effects of sAPP $\alpha$ were evident even after washout of the protein, revealing an ability of $\operatorname{sAPP} \alpha$ to cause a metaplastic state change in neurons that made them more conducive to the induction of late phase LTP.

\section{Materials and Methods}

\section{Animals}

All biochemical and electrophysiological experiments were conducted on tissue prepared from young adult male Sprague Dawley rats (42-56 d), as described previously (Mockett et al., 2007, 2011). All experimental procedures were performed under approval by the University of Otago's
Animal Ethics Committee and in accordance with New Zealand's animal welfare legislation. Group sizes were based on our previous studies of extrasynaptic receptors and electrophysiological analysis of LTP (Raymond et al., 2000; Williams et al., 2007; Taylor et al., 2008). Control treatments were routinely interleaved randomly between experimental treatments (electrophysiology, imaging) or undertaken at the same time in matched sets of wells (Western blots).

\section{Drugs and reagents}

Biochemical analyses. Complete protease inhibitor was purchased from Roche Diagnostics. The kinase inhibitors KN62, PD98059, and KT5823; the cell trafficking inhibitor Brefeldin A (BFA); and the NMDAR antagonist AP5 were from Tocris Biosciences. The protein synthesis inhibitors cycloheximide (CHX) and anisomycin were from Sigma-Aldrich.

Electrophysiological experiments. All buffer components were from BDH Chemicals. Blockers for AMPARs (CNQX), NMDARs (AP5, MK801), GABA ${ }_{A}$ Rs and $\mathrm{GABA}_{\mathrm{B}} \mathrm{Rs}$ (gabazine and CGP55845, respectively), metabotropic glutamate receptors (LY341495), glutamate transporters (TBOA), and protein synthesis (CHX), protein trafficking (BFA), and L-type voltage-dependent calcium channels (nimodipine) were from Tocris Bioscience and were dissolved in double-distilled water as stock solutions, except for nimodipine and BFA, which were dissolved in DMSO. QX-314 (Tocris Bioscience) was dissolved directly into the electrode solution. K-methanesulfonate, $\mathrm{Na}_{2} \mathrm{ATP}, \mathrm{NaGTP}$, phosphocreatine, and EGTA-4Na were from Sigma-Aldrich. All stock drug solutions were diluted 1:1000 with aCSF for the final working concentration. Vehicle treatment groups used DMSO in aCSF when comparisons were being made against drug treatments that involved the DMSO solvent.

Secreted amyloid precursor protein. Recombinant human sAPP $\alpha$ and sAPP $\beta$ were produced within cultured HEK $293 \mathrm{~T}$ cells in which the appropriate fragment of the APP gene had been stably integrated (Turner et al., 2007). It was secreted and purified from the culture media. The biological efficacy of our recombinant $\operatorname{sAPP} \alpha$, purified to a single band on an SDS polyacrylamide gel as analyzed by Coomassie blue staining and by Western analysis, has been validated in a variety of studies in vivo and in vitro, including electrophysiological and behavioral investigations (Turner et al., 2007; Taylor et al., 2008; Ryan et al., 2013). For receptor trafficking studies, heat-inactivated $\operatorname{sAPP} \alpha\left(100 \mu \mathrm{M}, 15 \mathrm{~min}\right.$ at $95^{\circ} \mathrm{C}$, $16,000 \times g$ for $1 \mathrm{~min}$ ) served as a negative control. The proteins were made into stock solutions in PBS and diluted in aCSF for the final working concentration.

\section{Hippocampal slice preparation for cell surface protein isolation}

Rats were deeply anesthetized with ketamine $(100 \mathrm{mg} / \mathrm{kg}$, i.p. $)$ and the brains were removed and chilled in ice-cold and oxygenated modified aCSF for which sucrose was substituted for $\mathrm{NaCl}$ containing the following (in mM): sucrose 210, glucose $20, \mathrm{KCl} 2.5, \mathrm{NaH}_{2} \mathrm{PO}_{4} 1.25, \mathrm{NaHCO}_{3}$ 26, $\mathrm{CaCl}_{2}$ 0.5, and $\mathrm{MgCl}_{2} 3$, pH 7.4 when gassed with $95 \% \mathrm{O}_{2}-5 \% \mathrm{CO}_{2}$. Hippocampi were dissected and slices $(400 \mu \mathrm{m})$ cut in a manner similar to that described previously (Mockett et al., 2004, 2011) using a Vibroslicer (Leica, VT1000). Slices were further dissected to contain only CA1 (CA1 mini-slices), bathed in standard aCSF containing the following (in mM): $\mathrm{NaCl} 124, \mathrm{KCl} 3.2, \mathrm{NaH}_{2} \mathrm{PO}_{4} 1.25, \mathrm{NaHCO}_{3} 26, \mathrm{CaCl}_{2} 2.5, \mathrm{MgCl}_{2}$ 1.3 , and D-glucose 10 equilibrated with carbogen $95 \% \mathrm{O}_{2} / 5 \% \mathrm{CO}_{2} ; 1$ $\mathrm{ml} / 2 \mathrm{~h} / 32^{\circ} \mathrm{C}$ ) in $35 \mathrm{~mm}$ tissue culture dishes ( 5 mini-slices/dish; one dish per treatment with multiple replicates) and held under interface conditions in a static incubation chamber containing an oxygen-rich and humidified atmosphere. sAPP $\alpha$ and other drug treatments were subsequently bath applied in fresh oxygenated and warmed aCSF for $30 \mathrm{~min}$. When studying inhibitor effects on $\operatorname{sAPP} \alpha$ treatment, slices were preincubated for $10 \mathrm{~min}$ with the inhibitors before subsequent coincubation with sAPP $\alpha$ for $30 \mathrm{~min}$.

Hippocampal cell surface proteins were isolated by tagging with a membrane-impermeable biotin moiety and precipitated by addition of Neutravidin conjugated to agarose beads using a modified method based on our established protocol (Williams et al., 2007). After drug treatments, slices were removed to ice-cold aCSF ( $5 \mathrm{~min}$ ) followed by incubation with $2.5 \mathrm{mg} / \mathrm{ml}$ sulfo-NHS-SS-biotin (45 min; Pierce, 21331). Unreacted biotin reagent was quenched by addition of $20 \mathrm{~mm}$ Tris- $\mathrm{HCl}$, 
$\mathrm{pH} 7.4$, and removed by washing $(3 \times 1 \mathrm{~min})$. Slices were then transferred to $1.5 \mathrm{ml}$ Eppendorf tubes and immediately snap-frozen on dry ice before being stored at $-80^{\circ} \mathrm{C}$ until further processing.

Postcollection processing of slices for cell surface protein analysis involved disruption of cell membranes by homogenization and sonication in solubilization buffer containing the following: $1 \mathrm{~mm}$ EGTA, $1 \mathrm{~mm}$ EDTA, 1 mM PMSF, complete protease inhibitor (Roche), 1\% (v/v) Triton X-100 (Bio-Rad) and 0.1\% (w/v) SDS in PBS. Proteins levels were estimated (BCA protein assay; Thermo Scientific) using $200 \mu \mathrm{g}$ per sample. Biotin-bound proteins were precipitated by the addition of Neutravidin conjugated to agarose beads $\left(2 \mathrm{~h}, 4^{\circ} \mathrm{C}\right.$; Pierce, 29200). Cell surface proteins were released from the biotin-neutravidin complex by incubation in $50 \mathrm{~mm}$ Tris-HCl, $\mathrm{pH} 8.0,1 \%$ (w/v) SDS, and $100 \mathrm{~mm}$ DTT (10 $\min , 99^{\circ} \mathrm{C}$ ). After sedimentation of the agarose beads, supernatants were aliquoted and stored at $-20^{\circ} \mathrm{C}$ before Western blot analysis.

\section{Quantitative Western blot analysis}

For analysis of whole-cell extracts, aliquots containing $25 \mu \mathrm{g}$ of protein were subjected to Western blot analysis. For analysis of cell surface proteins, a fixed volume $(25 \mu \mathrm{l})$ of cell extracts containing equal amounts of protein was used according to methods previously shown to give consistent and reproducible results (Williams et al., 2003, 2007). Whole-cell extracts from CA1 mini-slices were prepared as per Mockett et al. (2011). Protein extracts were separated by SDS-PAGE (acrylamide 9\% w/v) and transferred to nitrocellulose membrane (GE Healthcare Life Sciences). Membranes were probed with antibodies recognizing GluA1 (Abcam, ab31232), GluA1 phospho-Ser845 (Millipore, AB5849), GluA1 phospho-Ser831 (Invitrogen, 36-8200), GluA2 (Invitrogen, 32-0300), GluN1 (Invitrogen, 32-0500), GluN2A (Abcam, ab78483), GluN2B (BD Biosciences, 610417), CaMKII $\alpha$ (Sigma-Aldrich, C6974), phosphoCaMKII $\alpha$ (pThr286; Sigma-Aldrich, P-247), or $\alpha$-tubulin (Abcam, ab4074), which served as a loading control for the whole-cell extracts detected using either appropriate HRP-conjugated secondary antibodies and chemiluminescent reagent (GE Healthcare) or using the appropriate IgG-IRDye 680/800-conjugated secondary antibodies (Millennium Science, 926-32221, 926-32210) and visualized using the LI-COR Odyssey Infrared Fluorescence Imaging system.

For chemiluminescence detection of antibody binding, incubations were performed essentially as described previously (Williams et al., 1998). X-ray films were scanned using a Bio-Rad imaging densitometer and quantified using Molecular Analyst software. All data were generated from within-membrane comparisons and densitometric analysis was performed within the linear range of the film. For fluorescence detection of antibody binding, incubations were performed essentially as described previously (Mockett et al., 2011). Fluorescent images were visualized using the LI-COR Odyssey Infrared Imaging System and quantified using LI-COR Image Studio version 4.0.21. Background levels were subtracted from the relative intensity of each band. The most effective background subtraction method was determined for each blot using the coefficient of variation.

\section{Western blot experimental design and statistical analysis}

Data were subjected to a two-step normalization procedure to account for potential variation in amount of protein between samples due to difference in the thickness of slices and other potential experimental parameters. First, for the whole-cell extracts, background-subtracted integrated intensity values for each protein assessed were expressed relative to the level of $\alpha$-tubulin (tubulin-normalized). Second, the cell surface levels were expressed relative to the whole-cell extract tubulin-normalized values. Using GraphPad Prism (version 6.0), the datasets were tested for statistically significant outliers using the Grubb's test (significance level: $p<0.05$ ). All data were tested for normality (Shapiro-Wilk test) and for homogeneity of variance (Levene's test).

Linear mixed models (LMMs). The effects of sAPP $\alpha$ on GluA1, GluA2, and GluN1 expression level (dependent variable) were determined using LMMs (regression; SPSS). In the models, litter and individual animal numbers were used as random effects to account for the clustering within litters and animals, respectively, whereas the $\operatorname{sAPP} \alpha$ concentration [no drug (ND) controls, 0.3, 1, 10, and $100 \mathrm{~nm}$ and heat-inactivated $100 \mathrm{~nm}$ ] was used as the fixed effect. Model fit was assessed visually with histograms of residuals (normality) and scatterplots of residuals against fitted values (homoscedasticity). Following a Wald test for overall effect, Fisher's least significant difference (LSD) post hoc tests were used to perform planned pairwise comparisons of ND versus $\operatorname{sAPP} \alpha$ at each concentration. Data are presented as estimated marginal means \pm SEM (see Figs. $2 b, d, 3 b)$. The significance level was $p<0.05$ in all experiments.

Paired $t$ tests were used to assess the effect of sAPP $\alpha(1 \mathrm{nM})$ on GluN2A and GluN2B levels (see Fig. 3d) using GraphPad Prism version 6.0. For consistency with the GluN1 analysis, data are presented as tubulinnormalized values (see Fig. $2 d$ ). The significance level was $p<0.05$ in all experiments.

The effect of inhibitors was assessed by expressing the normalized $\operatorname{sAPP} \alpha(1 \mathrm{nM})$ values + inhibitor relative to inhibitor alone. Data are presented as fold change relative to ND (mean \pm SEM). To determine whether there was a significant difference between the mean effect of $\operatorname{sAPP} \alpha$ alone ( $1 \mathrm{~nm}$; fold change relative to ND) and each inhibitor $(\operatorname{sAPP} \alpha(1 \mathrm{nM})+$ inhibitor/ inhibitor), the data were subjected to paired Student's $t$ test adjusted for multiple comparisons using the Holm-Bonferroni sequential method (see Figs. $2 f, h, 3 f, 6 b, c$ ).

One-sample $t$ tests were used to assess the effect of $\operatorname{sAPP} \alpha(1 \mathrm{~nm})$ on GluA1 p-Ser831, GluA1 p-Ser845 (see Fig. $2 h$ ), and pCaMKII $\alpha$ (data not shown) using GraphPad Prism version 6.0 software. The significance level was $p<0.05$ in all experiments.

\section{FUNCAT-PLA}

Measurement of newly synthesized proteins in primary hippocampal neuronal cultures was conducted according to the method of tom Dieck et al. (2015) In brief, primary hippocampal neurons were prepared and cultured from P0 Sprague Dawley rat pups for 25-26 d in glass bottom dishes (MatTek). Standard growth medium (Neurobasal-A supplemented with B27 and GlutaMAX-I, Life Tech) was replaced with methionine-free Neurobasal A medium containing the methionine ana$\log$ azidohomoalanine (AHA; $4 \mathrm{~mm}$ ), along with anisomycin $(40 \mu \mathrm{M})$ to inhibit protein synthesis, or $\mathrm{sAPP} \alpha(1 \mathrm{nM})$ for $2 \mathrm{~h}$. Following incubation, cells were fixed with chilled $4 \%$ PFA in PBS, pH 7.4. Cells were permeabilized using $0.5 \%(\mathrm{v} / \mathrm{v})$ Triton X-100 in PBS, pH 7.4 (studies looking at cell surface protein expression had this step omitted) and blocked (4\% v/v normal goat serum in PBS). Cells were washed with PBS, $\mathrm{pH} 7.8$, and biotinylated overnight in "click-mix" containing the triazole ligand Tris((1-benzyl-1H-1,2,3-triazol-4-yl)methyl)amine (TBTA, $200 \mu \mathrm{M}$, TCEP-HCl $(500 \mu \mathrm{M})$, acetylene-PEG4-biotin-alkyne (25 $\mu \mathrm{M}$; Jena Bioscience) and $\mathrm{CuSO}_{4}(200 \mu \mathrm{M})$. To detect biotinylated proteins, cells were incubated with primary antibody (mouse anti-biotin (Sigma-Aldrich, B7653, 1:1000) diluted in 4\% (v/v) goat serum in PBS, $\mathrm{pH} 7.4)$, either alone for total synthesis experiments or in conjunction with rabbit antiGluA1 (Abcam, 31232, 1:1000) or rabbit anti-GluA2 (Abcam, 133477, $1: 150$ ) for $90 \mathrm{~min}$ at room temperature (RT). Cells were further incubated with Duolink reagents (Plus and Minus probes) for $60 \mathrm{~min}$ at $37^{\circ} \mathrm{C}$. For global protein synthesis, to detect all biotin-antibody complexes, both Plus and Minus probes recognized mouse IgG (Duolink In situ PLA probe anti-mouse, DUO92001 and DUO92004). For GluA1- and GluA2targeted experiments, the biotin-IgG complexes were detected with the Minus probe as above and GluA1 or GluA2 were detected with Plus probes comprising polyclonal antibodies recognizing rabbit IgG conjugated with Plus Oligonucleotides (Duolink In Situ PLA probe antirabbit, DUO92002). For detection, cells were subsequently incubated with ligation mixture for $30 \mathrm{~min}$ at $37^{\circ}$ followed by the amplification mixture (Duolink detection reagents red, DUO92008) for $100 \mathrm{~min}$ at $37^{\circ} \mathrm{C}$. This allows for ligation and amplification of Plus and Minus probes in close proximity and thus detection of newly synthesized proteins.

Following blocking in $4 \%(\mathrm{v} / \mathrm{v})$ goat serum in PBS, $\mathrm{pH} 7.4$, overnight, cells were probed with a dendritic marker, guinea pig anti-MAP2 (Synaptic Systems, 188004, 1:2000), then washed and incubated with fluorescent secondary antibody (Alexa Fluor 488 goat-anti-guinea pig; Life Technologies, A-11073, 1:1000) and DAPI to detect nuclei (Roth, 6335, $1: 1000$ ) for $30 \mathrm{~min}$ at RT.

Imaging. A representative sample of neurons was imaged per dish using an LSM-780 confocal microscope (Zeiss) with a $40 \times / 1.4$ numerical 
aperture oil-immersion objective and a pinhole setting of $90 \mu \mathrm{m}$. Images were acquired in 8-bit $z$ stacks with the $x-y$ resolution covering the entire cell. Laser power was maintained at $2 \%$ and gain was set such that no saturated pixels occurred. Identical imaging settings were used within an experiment regardless of treatment group.

\section{FUNCAT-PLA experimental design and statistical analysis}

Image analysis. Images were analyzed using a custom-made ImageJ script (Maximilian Heumüller, Max Planck Institute for Brain Research). Following thresholding of the FUNCAT-PLA signal, a "MAP2 mask" was generated capturing the area of the neuron and the size and intensity of FUNCAT-PLA puncta within the mask were measured and recorded. To analyze the signal within the somatic and dendritic compartments, somata were isolated from each cell as above and all dendrites were straightened using the "straighten" plugin in ImageJ. The proximal $50 \mu \mathrm{m}$ segment was analyzed for PLA signal as described above. For image representation, ImageJ was used to adjust the brightness and contrast of maximum-intensity projections equally for all treatment groups and to dilate the FUNCAT-PLA signal using the "dilate" function to allow for better visualization.

Statistical analysis. An "integrated intensity/neuronal area” value was generated for each cell. Data were normalized by expressing treated groups relative to the average of the controls for that experiment. Data (see Fig. 6) exhibited a non-normal distribution as detected by the D'Agostino and Pearson normality test. One-way ANOVA with KruskalWallis and Dunn's multiple-comparisons post hoc tests were used to determine significance with $p<0.05$ accepted as statistically significant.

\section{Hippocampal slice preparation for electrophysiology}

Transverse hippocampal slices $(400 \mu \mathrm{m})$ were prepared as described in the biochemistry section (Mockett et al., 2004, 2011) before being transferred to an oxygenated and humidified static incubation chamber where they were placed on Millicell culture plate inserts (Millipore) in interface contact with aCSF and held at $32^{\circ} \mathrm{C}$ for at least $30 \mathrm{~min}$ to equilibrate. The incubation chamber was then allowed to cool to room temperature and the slices were held for at least a further $90 \mathrm{~min}$.

\section{Field potential electrophysiology}

The aCSF for field recordings consisted of the following (in $\mathrm{mm}$ ): $\mathrm{NaCl}$ 124, $\mathrm{KCl} 3.2, \mathrm{NaH}_{2} \mathrm{PO}_{4} 1.25, \mathrm{NaHCO}_{3} 26, \mathrm{CaCl}_{2} 2.5, \mathrm{MgCl}_{2} 1.3$, and D-glucose 10 and was equilibrated with carbogen $\left(95 \% \mathrm{O}_{2}-5 \% \mathrm{CO}_{2}\right)$. Following $2 \mathrm{~h}$ recovery in the incubation chamber, slices were transferred to a recording chamber through which aCSF equilibrated with carbogen was superfused continuously at a rate of $2 \mathrm{ml} / \mathrm{min}$ and maintained at a temperature of $32.5^{\circ} \mathrm{C}$. Baseline field EPSPs (fEPSPs) were elicited in area CA1 by stimulation of the Schaffer collateral-commissural pathway at $0.017 \mathrm{~Hz}$ (diphasic pulses, $0.1 \mathrm{~ms}$ half-wave duration) using a Tefloncoated $50 \mu \mathrm{m}$ tungsten wire monopolar electrode (A-M Systems). Evoked responses were recorded with a glass microelectrode filled with aCSF (2-3 M $\Omega$ ) and placed in stratum radiatum of area CA1. During periods of baseline recording, the stimulation intensity was adjusted to elicit a fEPSP with an initial slope value of $40 \%$ of the maximum elicited when delivering $200 \mu \mathrm{A}$ of current. Drugs, including $\operatorname{sAPP} \alpha$, were bath applied by switching to an identical preheated and oxygenated aCSF solution that contained the compound of interest. Inhibitors were delivered for $10 \mathrm{~min}$ before and during $\operatorname{sAPP} \alpha$ administration. Nonsaturated LTP was induced by applying a "half" train of standard theta-burst stimulation (0.5 TBS; 5 trains of 5 pulses at $100 \mathrm{~Hz}$ delivered at $200 \mathrm{~ms}$ intervals) at baseline stimulus intensity (Raymond et al., 2000).

To determine whether changes in presynaptic function contribute to the effects of sAPP $\alpha$ on LTP expression, we conducted two electrophysiological tests that provide indirect measures of presynaptic responses following electrical stimulation. Presynaptic paired-pulse facilitation (PPF) was tested in stratum radiatum immediately before and following $30 \mathrm{~min}$ of $\mathrm{sAPP} \alpha$ perfusion by delivering paired stimuli ( 3 pairs at $10 \mathrm{~s}$ intervals) at interpulse intervals ranging from 20 to $200 \mathrm{~ms}$ in the presence of AP5 $(50 \mu \mathrm{M})$. PPF was expressed as a ratio and was calculated as EPSP 2 amplitude/EPSP 1 amplitude. Posttetanic potentiation (PTP) was evaluated in the same slices as PPF testing by delivery of 3 bouts of 0.5 TBS separated by $30 \mathrm{~s}$ with a recording interpulse interval of $5 \mathrm{~s}$. PTP was also expressed as a ratio and was calculated as the first post-TBS EPSP amplitude/the average of the immediate three pre-TBS EPSP amplitudes.

\section{Patch-clamp electrophysiology}

Standard whole-cell patch-clamp techniques were used to record extrasynaptic EPSCs $s_{\text {NMDAR }}$ from the cell body of visualized CA1 pyramidal neurons. Patch electrodes were formed from soft borosilicate glass (WPI) and filled with a $\mathrm{K}^{+}$-based electrode solution containing the following (in mM): K-methanesulfonate 145, HEPES 10, $\mathrm{Na}_{2} \mathrm{ATP} 4$, NaGTP 0.4, $\mathrm{MgCl}_{2} 4, \mathrm{Na}_{2}$ phosphocreatine 10, EGTA-4 Na 0.2, and QX-314 1, pH 7.4 adjusted with $\mathrm{KOH}, 310 \mathrm{mOsm}$ adjusted with water, to give resistances of 2.5-3 $\mathrm{M} \Omega$. Access resistance (typically $10-20 \mathrm{M} \Omega$ ) was assessed at the beginning and end of each experiment and experiments that differed by $>30 \%$ of baseline values were discarded. AMPARs, $\mathrm{GABA}_{\mathrm{A}} \mathrm{Rs}$, and $\mathrm{GABA}_{\mathrm{B}}$ Rs were blocked before cell attachment with bath-applied CNQX $(10 \mu \mathrm{M})$, gabazine $(5 \mu \mathrm{M})$, and CGP55845 $(1 \mu \mathrm{M})$, respectively, to reveal the synaptic EPSC $_{\mathrm{NMDAR}}$. Voltage-dependent calcium currents due to L-type channels were inhibited with bath-applied nimodipine $(10 \mu \mathrm{M})$. Single synaptic EPSCs NMDAR $_{\text {S }}(200-800 \mathrm{pA})$ were recorded in voltageclamp mode at a holding potential of $-30 \mathrm{mV}$ using an Axopatch $1 \mathrm{D}$ amplifier and pCLAMP 9 software (Molecular Devices). Initial responses were elicited once every $30 \mathrm{~s}$ by electrical stimulation of the Schaffer collaterals via a wide-bore pipette filled with aCSF and placed in the stratum radiatum. Extrasynaptic EPSCs ${ }_{\mathrm{NMDAR}}$ were elicited by first blocking synaptic EPSCs ${ }_{\text {NMDAR }}$ s by bath perfusion with the noncompetitive activity-dependent NMDAR blocker MK801 (50 $\mu \mathrm{M})$ while stimulating at a rate of once every $5 \mathrm{~s}$ until this response was abolished. MK801 was then washed out for $20 \mathrm{~min}$ in the absence of further electrical stimulation. A new baseline (typically showing near $0 \mathrm{pA}$ synaptic currents) at the same current intensity was then recorded for 10 min before extrasynaptic NMDAR activity was elicited by bath perfusion of the glutamate reuptake inhibitor TBOA $(50-100 \mu \mathrm{M})$ and the NMDAR agonist glycine $(30 \mu \mathrm{M})$. This allowed released glutamate to escape the synaptic cleft and activate extrasynaptic NMDARs. When the effect of sAPP $\alpha$ ( $1 \mathrm{~nm})$ on

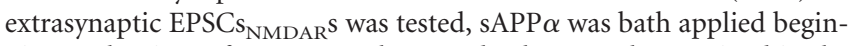
ning at the time of MK801 washout and subsequently remained in the aCSF for the duration of the experiment.

\section{Electrophysiology experimental design and statistical analysis}

The initial slopes of the fEPSPs were measured and expressed as a percentage change from the baseline level calculated as the average of the last 15 min of the baseline recording period (Mockett et al., 2002). Group means were expressed as the percentage change \pm SEM. Extrasynaptic EPSC $_{\text {NMDAR }}$ peak current amplitudes during TBOA application were measured and expressed as the mean \pm SEM. For all experiments, outlier data points were defined as $>2$ SDs from the mean and excluded from analyses. Group means (see Figs. 1, 4, 5, 7) were compared statistically by two-tailed independent Student's $t$ tests and one-way ANOVAs with Dunnett's post hoc tests (inhibitor studies; see Figs. 4, 7) at the $p<0.05$ significance level.

\section{Data availability}

The data that support the findings of this study are available from the corresponding author upon reasonable request.

\section{Results \\ sAPP $\alpha$ facilitates both LTP induction and persistence}

Previous studies have shown that exogenous sAPP $\alpha$ is most effective at promoting LTP either when submaximal tetanization protocols are used or when LTP is impaired (Taylor et al., 2008; Hick et al., 2015; Moreno et al., 2015). Here, we used a mild TBS protocol in area CA1 of hippocampal slices with a vehicle control that generates only an early-LTP (E-LTP, also termed LTP1; Raymond et al., 2000), which is decremental and protein synthesis independent (Raymond et al., 2000). Use of this protocol enabled investigation of sAPP $\alpha$ 's effects on both induction and persistence of LTP. When applied $25 \mathrm{~min}$ before, during, and for $5 \mathrm{~min}$ after the delivery of TBS, sAPP $\alpha$ ( $1 \mathrm{nM})$ did not significantly affect 

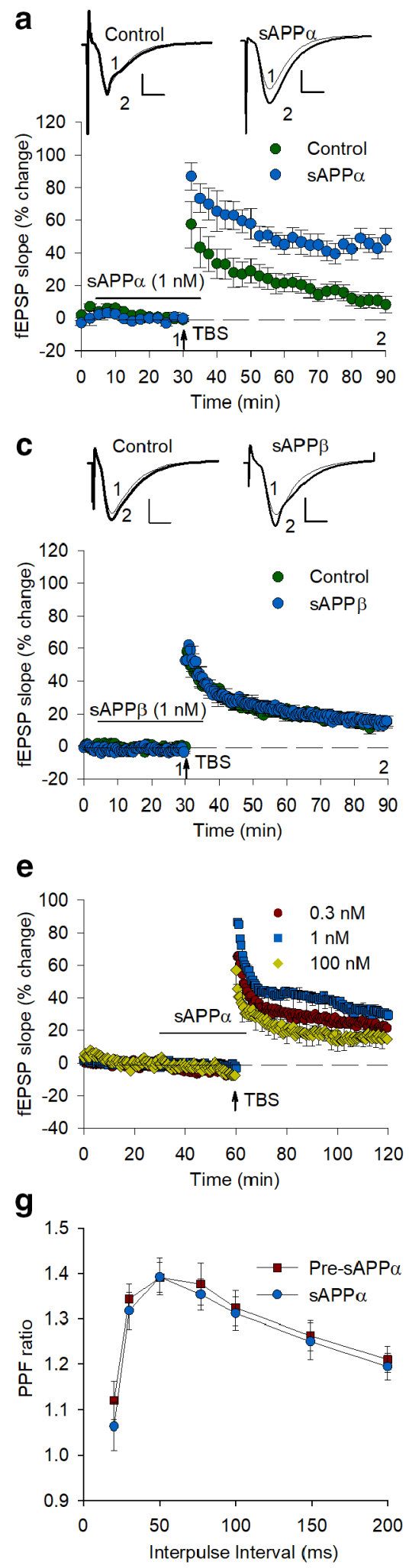

Figure 1. $\quad \operatorname{SAPP} \alpha$ facilitates the induction and stabilization of LTP in rat hippocampus in a concentration dependent manner. $\boldsymbol{a}$ Control slices ( $n=11$ slices, 7 rats) receiving only a mild TBS ( 5 bursts at $5 \mathrm{~Hz}, 5$ pulses at $100 \mathrm{~Hz} /$ burst) exhibited a rapidly decaying form of LTP. In contrast, sAPP $\alpha$ (1 nM, $n=7$ slices, 4 rats) bath applied from 25 min before until 5 min after TBS significantly facilitated both the initial induction and the persistence of LTP as measured 60 min later. $\boldsymbol{b}$, Summary histogram showing level of potentiation 0-5 min after TBS and LTP level 50-60 min after TBS for each group in $\boldsymbol{a}$. c, SAPP $\beta$ ( $1 \mathrm{~nm}, n=6$ slices, 4 rats) administered by the same protocol failed to affect LTP compared with a new control group ( $n=9$ slices, 8 rats), demonstrating that the LTP facilitation is specific to SAPP $\alpha$ and is not a side effect of protein administration generally or of contaminants in the protein preparations. $\boldsymbol{d}$, Summary histogram showing levels of potentiation $0-5$ min after TBS and LTP level $50-60$ min after TBS for each group in c. Statistics performed by Student's $t$ tests on data expressed relative to control. Insets, Example fEPSPs for each group the Schaffer collateral/commissural baseline responses, consistent with what we have previously reported (Taylor et al., 2008). However, it significantly facilitated both the initial induction and the persistence of LTP. Potentiation averaged over the first 5 min after TBS was significantly greater in the sAPP $\alpha$ group $(79.4 \pm 8.9 \%)$ compared with the control group (47.5 \pm $10.3 \%, t_{(16)}=2.12, p=0.047$; Fig. $\left.1 a, b\right)$ and the degree of LTP measured $1 \mathrm{~h}$ after TBS was greater in the sAPP $\alpha$ group (control: $8.5 \pm 3.8 \%$; sAPP $\alpha$ : $44.4 \pm 6.6 \%, t_{(16)}$ $=5.05, p=0.0001$; Fig. $1 a, b)$. To confirm the enhanced persistence, we fitted doublenegative exponential curves to the LTP data and found that the average decay time constant of the second slower exponential of the sAPP $\alpha$-treated slices (111.1 min) was significantly greater than for the control group (34.0 min, $t_{(16)}=2.74, p=$ 0.015). Neither a lower concentration of $0.3 \mathrm{~nm}(22.9 \pm 10.3 \%)$ nor a higher concentration of $100 \mathrm{~nm}(15.9 \pm 5.6 \%)$ facilitated LTP (Fig. 1e,f). This inverted U-shaped concentration dependency of the sAPP $\alpha$ effect is similar to that reported previously for the sAPP $\alpha$ regulation of LTP in vivo (Taylor et al., 2008) and synaptic protein synthesis in vitro (Claasen et al., 2009). In contrast to $\operatorname{sAPP} \alpha$, secreted APP-beta ( $\mathrm{APP} \beta)$, which differs from sAPP $\alpha$ only by lacking its C-terminal 16 aa, had no effect on LTP induction or persistence (50-60 min: $18.1 \pm 2.6 \%$ ) at the $1 \mathrm{nM}$ concentration that was maximally effective for $\operatorname{sAPP} \alpha$ (Fig. $1 c, d)$. This latter finding is consistent with prior studies showing a lack of effect of $\operatorname{sAPP} \beta$ in

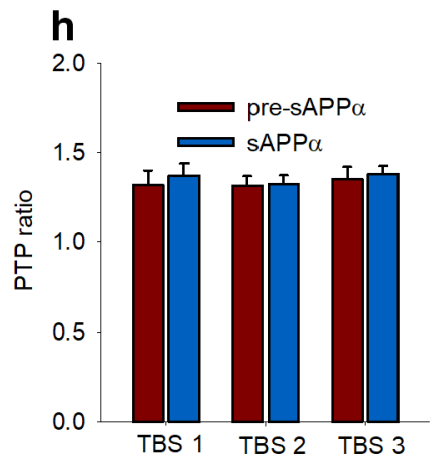

$\leftarrow$

presented as a 10 trace average taken at the end of the baseline (1) and 55-60 min after TBS (2). Scale bars $1 \mathrm{mV}, 5 \mathrm{~ms}$., SAPP $\alpha$ facilitation of LTP is concentration dependent. sAPP $\alpha$ ( $1 \mathrm{~nm}, n=8$ ) applied for 30 min to hippocampal slices induced a significant facilitation of LTP induction and persistence measured $1 \mathrm{~h}$ after TBS delivery compared with the untreated control group $(n=9)$. In contrast, neither $0.3 \mathrm{~nm}(n=6)$ nor 100 $\mathrm{nм}(n=5) \mathrm{SAPP} \alpha$ facilitated LTP induction or persistence. $\boldsymbol{f}$, Summary histogram showing levels of LTP induction $(0-5$ min after TBS) and persistence (50 - 60 min after TBS). Statistics were performed using ANOVA followed by Dunnett's post hoc test. $\boldsymbol{g}$, sAPP $\alpha$ does not alter electrophysiological measures of presynaptic function. PPF, determined across a range of interpulse intervals, was not altered by sAPP $\alpha(1 \mathrm{~nm}, n=6)$ delivery for 30 min before testing. $\boldsymbol{h}$ Presynaptic PTP, measured 5 s after each of 3 TBS protocols delivered at 30 s intervals in the presence of $A P 5$, was unchanged by application of sAPP $\alpha(1 \mathrm{~nm}, n=4)$ for 30 min before the first TBS. Findings in $\boldsymbol{g}$ and $\boldsymbol{h}$ indicate that the effect of SAPP $\alpha$ on LTP facilitation is not mediated by changes in presynaptic function. All data are shown as mean percentage change \pm SEM. Arrow indicates the time of TBS delivery. ${ }^{*} p<0.05 ;{ }^{* *} p<0.01$; ${ }^{* * *} p<$ 0.001 . 
a

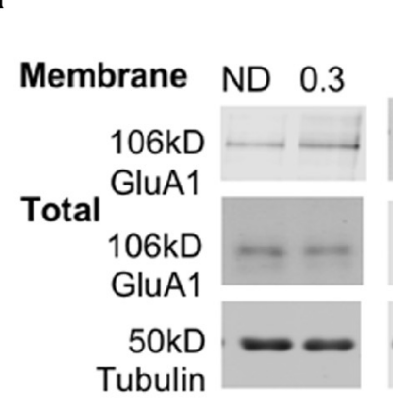

$\operatorname{sAPP} \alpha(n M)$

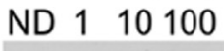

ND $100 \mathrm{HI}$

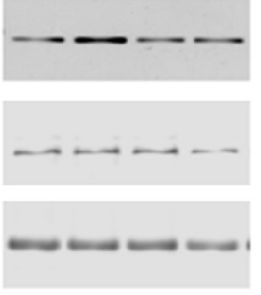

b
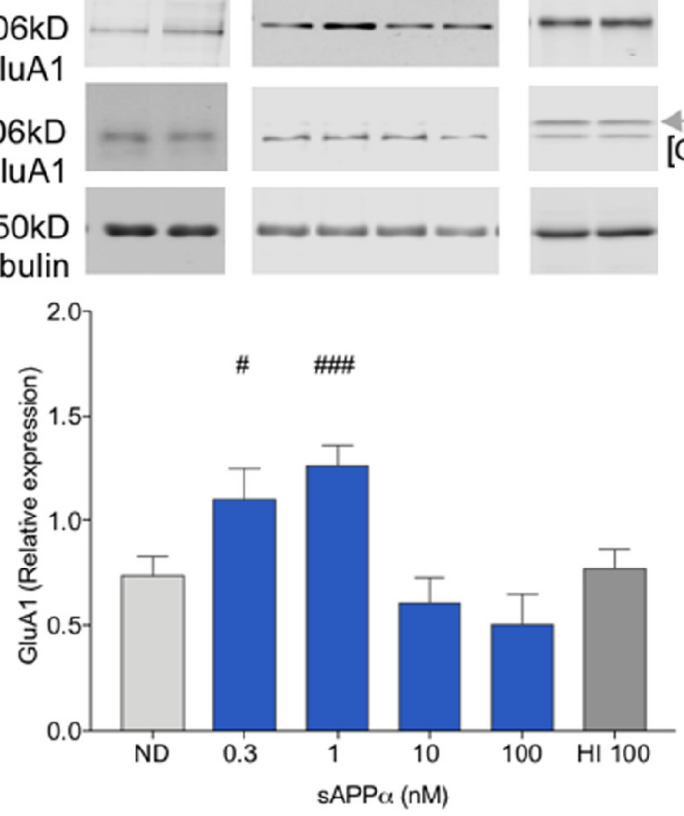

C

d

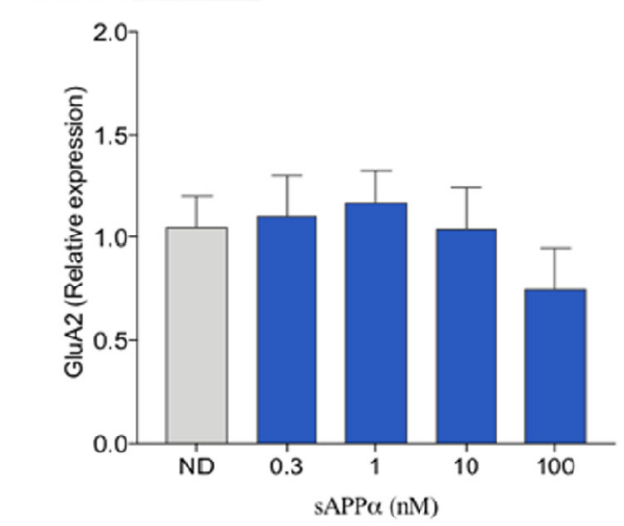

[GluN1]

Membrane

e

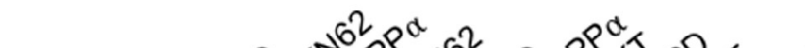

Membrane

106kD

GluA1

Total

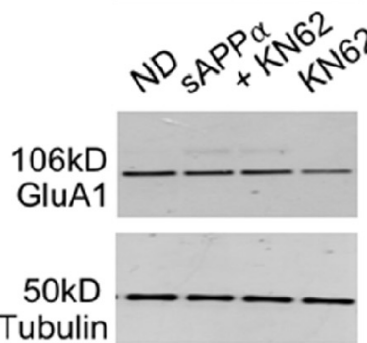

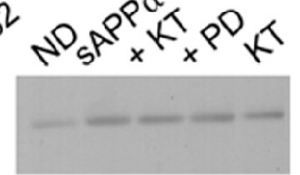

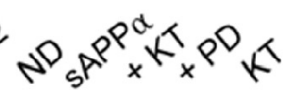
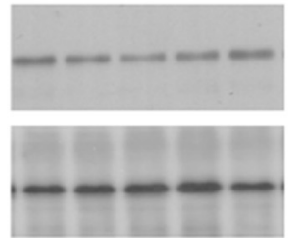
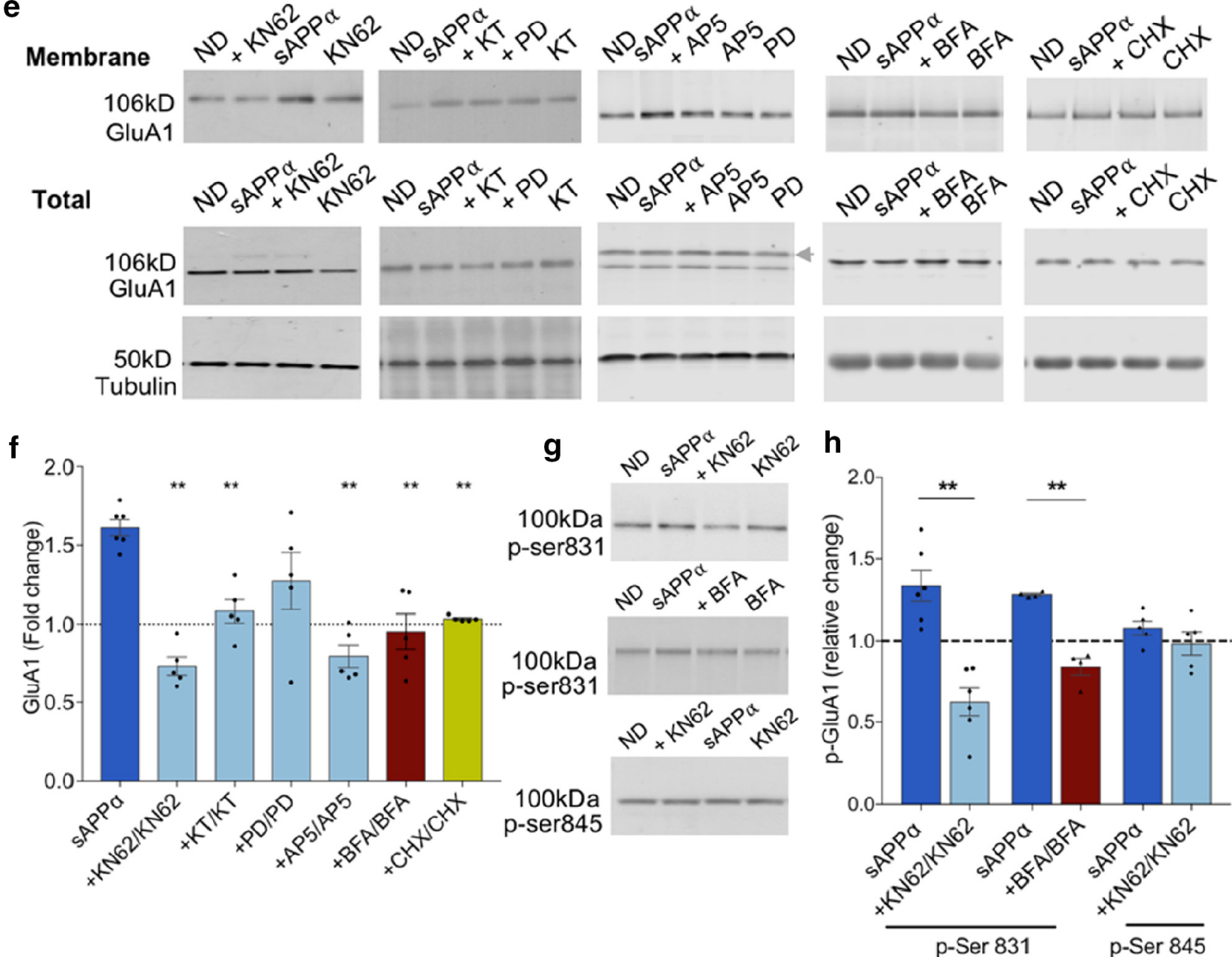

Figure 2. SAPP $\alpha$ promotes the trafficking of GluA1, but not GluA2, subunits to the cell surface. $\boldsymbol{a}, \boldsymbol{b}$, Representative Western blots for GluA1 (106 kDa) (a) and tubulin (50 kDa) (b) summary data showing that $\mathrm{SAPP} \alpha(1 \mathrm{~nm}, 30 \mathrm{~min})$ increased biotin-labeled cell surface GluA1 levels in cell extracts from hippocampal slices in a concentration-dependent manner [LMM: control, $n=44$ ( 9 clusters; litters); $0.3 \mathrm{~nm}, n=5 ; 1 \mathrm{nм}, n=35$ (8clusters; litters); $10 \mathrm{~nm}, n=10 ; 100 \mathrm{~nm}, n=5 ; 100 \mathrm{~nm}$ heat-inactivated (HI), $n=4]$. Data represent estimated marginal means \pm SE. (Figure legend continues.) 
rescuing LTP in area CA1 in vitro (Hick et al., 2015; Richter et al., 2018), as well as in the dentate gyrus in vivo (Taylor et al., 2008).

To determine whether the ability of $\operatorname{sAPP} \alpha$ to facilitate LTP was due at least in part to altered presynaptic function, we measured the effect of $\operatorname{sAPP} \alpha(1 \mathrm{nM})$ on PPF across a range of interpulse intervals under baseline conditions, as well as posttetanic potentiation following TBS in the presence of AP5 to prevent LTP induction. Neither of these measures of presynaptic activity was altered by $\operatorname{sAPP} \alpha$ treatment (Fig. $1 g, h$ ), suggesting that the facilitatory effect of $\operatorname{sAPP} \alpha$ on LTP was exerted at postsynaptic sites, confirming our conclusions from previous study (Taylor et al., 2008).

We also tested whether sAPP $\alpha$ would regulate long-term depression (LTD) because it too has a late phase that is dependent on protein synthesis and involves altered receptor expression. However, sAPP $\alpha$ ( $1 \mathrm{nM})$ had no significant effect on LTD induced by either a moderate protocol $(900$ pulses at $1 \mathrm{~Hz}$ : control $-17.6 \pm 7.3 \%, n=8 ; \operatorname{sAPP} \alpha-24.9 \pm 5.2 \%, n=9)$ or a strong protocol (1200 pulses at $1 \mathrm{~Hz}$ : control $-24.2 \pm 4.3 \%, n=8$; sAPP $\alpha-32.9 \pm 10.5 \%, n=5$ ) (Mockett et al., 2002). Because there was a lack of any significant effect on LTD under these conditions, the remaining experiments focused on the effect of $\operatorname{sAPP} \alpha$ on LTP.

\section{sAPP $\alpha$ increases GluA2-lacking AMPARs at the cell surface}

Because SAPP $\alpha$ enhanced the initial induction of LTP, but did not affect presynaptic plasticity, we hypothesized that sAPP $\alpha$ may contribute to LTP induction by increasing trafficking of glutamate receptors to the cell membrane of the postsynaptic cell, where they would be well placed to translocate to the synapse in response to TBS (Sun et al., 2005; Oh et al., 2006). We tested this using hippocampal slices prepared in a manner similar to that used for electrophysiology. The slices were first treated with $\operatorname{sAPP} \alpha$ (five slices/dish; one dish per treatment) and then the surface proteins labeled with biotin before purification by Neutravidin pulldown. Western blots were used to analyze the biotinlabeled sequestered proteins. Cell surface levels were expressed relative to the total cellular glutamate receptor levels, which in turn were normalized to $\alpha$-tubulin. To account for the interleaved experimental design, where each experiment comprised, for example, "ND" and 1 nM sAPP $\alpha$, data were analyzed using an LMM (regression). This allowed clustering of the data according to experiments and accounted for the concomitant increase in biological replicates in the ND and $1 \mathrm{nM} \operatorname{sAPP} \alpha$-treated groups. We first established that the overall model was significant

\section{$\leftarrow$}

(Figure legend continued.) c, $\boldsymbol{d}$, Representative Western blots for GluA2 (96 kDa) (c) and LMM (d) summary data showing that cell surface GluA2 levels were not significantly affected by sAPP $\alpha$ treatment (control, $n=10 ; 0.3 \mathrm{~nm}, n=5 ; 1 \mathrm{~nm}, n=10 ; 10 \mathrm{~nm}, n=5 ; 100 \mathrm{~nm}, n=5$ ). $\boldsymbol{e}, \boldsymbol{f}$, Specific kinase inhibitors revealed that $\triangle A P P \alpha$-induced GluA1 trafficking was dependent on $\mathrm{Ca}^{2+} / \mathrm{CaM}$-dependent protein kinases (KN62 $10 \mu \mathrm{M}, n=5$ ) and PKG [KT5823 (KT) $10 \mu \mathrm{m}, n=$ 5], but not significantly on ERK1/2 [PD98059 (PD), $50 \mu \mathrm{m}, n=5$ ]. Inhibition of NMDAR activation (AP5, $50 \mu \mathrm{M}, n=5$ ), protein trafficking (BFA, $35 \mu \mathrm{M}, n=5$ ) or protein synthesis with CHX ( $60 \mu \mathrm{M}, n=5)$ significantly blocked the SAPP $\alpha$-induced increase in cell surface GluA1 levels. Data from inhibitor studies are expressed as mean ratio of $\mathrm{SAPP} \alpha+$ drug/drug alone \pm SEM. Significance was assessed using paired $t$ tests. $\boldsymbol{e}$, Representative Western blots. Dashed line in $\boldsymbol{f}$ shows control level for the ND group (SAPP $\alpha$ ) and the drug-alone groups. $\boldsymbol{g}, \boldsymbol{h}$, GluA1 p-Ser831 $(100 \mathrm{kDa})$ was significantly increased by sAPP $\alpha$ treatment $(1 \mathrm{~nm}, n=6$; one-sample $t$ test $)$. This increase was completely blocked by KN62 $(n=6)$ and by BFA $(35 \mu \mathrm{m}, n=4)$. Cell surface GluA1 p-Ser845 $(100 \mathrm{kDa})$ was not significantly affected by sAPP $\alpha$ treatment $(1 \mathrm{~nm}, n=5)$ nor by KN62 (10 $\mu \mathrm{M}, n=5)$ in the presence of SAPP $\alpha$ (paired $t$ tests). For LMM pairwise comparisons (Fisher's LSD), \#p $<0.05$; \#\#\# $<0.001$; for paired $t$ test (Holm-Bonferroni multiplecomparisons correction), ${ }^{* *} p<0.01$.
$\left(F_{(5,56.2)}=23.070 ; p=1.618 \mathrm{E}^{-12}\right)$ and then used targeted pairwise comparisons (Fisher's LSD) to determine whether there was an effect of sAPP $\alpha$ on glutamate receptor cell surface levels.

We found that $\operatorname{sAPP} \alpha$ induced a concentration-dependent change in GluA1 cell surface expression (Fig. 2a,b). At $1 \mathrm{nM}$ $\operatorname{sAPP} \alpha$, there was a significant increase in GluA1 surface expression relative to vehicle control matched slices $\left(p=6.172 \mathrm{E}^{-13}\right.$; pairwise comparisons, estimated marginal mean \pm SE: ND $0.74 \pm 0.09 ; 1 \mathrm{nM} 1.27 \pm 0.09, n=44$, 9 clusters) without affecting the total level of cellular GluA1 (Fig. 2a). A lower concentration of $\operatorname{sAPP} \alpha(0.3 \mathrm{nM})$ caused a smaller but significant increase $(1.10 \pm 0.15, n=5, p=0.031)$, whereas a higher concentration of $\operatorname{sAPP} \alpha(100 \mathrm{nM}, n=5)$ had no significant effect. Heat-inactivated $\operatorname{sAPP} \alpha(100 \mathrm{nM}, n=4)$ was also tested to exclude the possibility that contaminants in the preparation were driving the decline in trafficking at this high concentration; however, this failed to unmask a baseline reduction $(p=1.0)$. This finding, together with the lack of effect by sAPP $\beta$, indicates that the observed trafficking effect was specific to $\operatorname{sAPP} \alpha$. In contrast to the effects on GluA1, $\operatorname{sAPP} \alpha$ did not affect GluA2 surface expression $\left(F_{(4,21)}=2.155\right.$; $p=0.110)$, indicating that the effect on receptor accumulation was not a general one, but selective for AMPARs that lacked the GluA2 subunit (Fig. 2c,d).

To investigate the signaling mechanisms underlying $\operatorname{sAPP} \alpha$ mediated GluA1 trafficking, we incubated slices with $\operatorname{sAPP} \alpha$ in the presence of kinase inhibitors known to regulate other actions facilitated by $\operatorname{sAPP} \alpha$. Data were normalized to treatment groups with antagonist alone. Coincubation of $\operatorname{sAPP} \alpha$ with either the CaMKII inhibitor KN62 or the PKG inhibitor KT5823 completely blocked the enhancement of GluA1 surface expression (KN62: $0.73 \pm 0.06$ mean $\pm \mathrm{SEM}, n=5, t_{(4)}=7.411, p=0.005$ paired- $t$ test, Holm-Bonferroni sequential multiple-comparison adjustment; KT5823: $1.08 \pm 0.07, n=5, t_{(4)}=5.879, p=0.008$; Fig. 2e,f). By contrast, inhibition of ERK1,2 with PD98059 resulted in only a partial inhibition such that GluA1 surface expression was not significantly different from $\operatorname{sAPP} \alpha$-treated levels $\left(t_{(4)}=2.218, p=0.0573\right)$. The sAPP $\alpha$-mediated increase in GluA1 surface expression was also blocked by the NMDAR antagonist AP5 ( $0.80 \pm 0.07, n=5, t_{(4)}=10.260, p=0.003$; Fig. $2 e, f)$.

These data demonstrate that exogenous $\operatorname{sAPP} \alpha$ enhances accumulation of GluA1 at the cell surface, but they do not distinguish between enhanced trafficking and reduced internalization. To resolve this question, we coincubated sAPP $\alpha$ with the trafficking inhibitor BFA. BFA completely blocked the $\operatorname{sAPP} \alpha$-induced GluA1 accumulation $\left(0.95 \pm 0.11, n=5, t_{(4)}=8.700, p=0.005\right.$; Fig. $2 e, f)$, suggesting that $\operatorname{sAPP} \alpha$ acts to modify the passage of GluA1 to the cell surface. We also tested whether GluA1 trafficking was protein synthesis dependent because KN62, PD98059, and KT5823 all reduced or blocked sAPP $\alpha$ 's upregulation of protein synthesis in synaptoneurosomes (Claasen et al., 2009). Indeed, the protein synthesis inhibitor CHX significantly reduced the sAPP $\alpha$-mediated increase in GluA1 cell surface expression within the $30 \mathrm{~min}$ time frame $\left(1.03 \pm 0.007, t_{(4)}=8.391, p=\right.$ 0.005; Fig. 2e,f).

The trafficking of GluA1-containing AMPARs into and out of the cell membrane is regulated in part by the phosphorylation state of two differentially controlled serine residues within GluA1: Ser845, phosphorylated by protein kinase A (PKA) and Ser831, phosphorylated by protein kinase C and CaMKII. Accordingly, first we tested the effect of $\operatorname{sAPP} \alpha$ on p-CaMKII levels in CA1 mini-slices. We found that $\operatorname{sAPP} \alpha(1 \mathrm{nM}, 10 \mathrm{~min})$ significantly increased p-CaMKII (pThr286) levels compared with 
control slices $\left(2.06 \pm 0.18, t_{(4)}=5.748, p=0.005, n=5\right.$; onesample $t$ test; data not shown). Given this and the complete block of sAPP $\alpha$-induced GluA1 trafficking by KN62, we investigated whether SAPP $\alpha$ regulates the phosphorylation of the Ser831 site on GluA1. Indeed, $\operatorname{sAPP} \alpha$ caused a significant increase in p-Ser831 of surface GluA1 to a similar extent as GluA1 (1.34 \pm $0.09 ; t_{(5)}=3.515, p=0.017, n=6$; one-sample $t$ test), an effect that was completely blocked by KN62 $\left(t_{(5)}=5.800, p=0.006\right.$; Fig. $2 g, h)$. BFA also completely blocked the sAPP $\alpha$-mediated increase in surface expression of GluA1 p-Ser831 $\left(t_{(3)}=8.097, p=\right.$ 0.008; Fig. $2 g, h)$. Neither sAPP $\alpha$ (1 nM) nor KN62 altered the phosphorylation state of surface GluA1 p-Ser845 (Fig. $2 g, h$ ). Collectively, these findings suggest that posttranslational phosphorylation of p-Ser831 within GluA1 may play a role in mediating the enhancement of GluA1 cell surface expression either through enhanced trafficking or diffusional trapping in the surface membrane.

\section{sAPP $\alpha$ increases trafficking of NMDARs to the cell surface}

We also determined whether SAPP $\alpha$ regulates NMDAR trafficking, focusing first on the obligatory subunit GluN1. As for GluA1/2, using LMM (regression), we first established whether the model was significant $\left(F_{(5,53.9)}=12.787, p=3.291 \mathrm{E}^{-8}\right)$ and using pairwise comparisons found that $\operatorname{sAPP} \alpha$ caused a significant increase in cell surface expression of GluN1 (ND estimated marginal mean \pm SE: $0.94 \pm 0.11, n=44,9$ clusters; $1 \mathrm{nM} \mathrm{sAPP} \alpha$ $1.33 \pm 0.12, p=6.849 \mathrm{E}^{-10}, n=35,8$ clusters; Fig. $\left.3 a, b\right)$ without affecting the total levels of GluN1 (Fig. $3 a$ ). This effect was concentration dependent because $0.3,10$, or $100 \mathrm{nM}$ concentrations $\operatorname{sAPP} \alpha$ had no effect, nor did heat-inactivated $\operatorname{sAPP} \alpha$ (Fig. $3 a, b)$. We also found that $\operatorname{SAPP} \alpha(1 \mathrm{nM})$ significantly increased the surface expression of GluN2B subunits (ND: $0.40 \pm 0.02, n=13 ; 1$ nм sAPP $\alpha 0.46 \pm 0.03, t_{(12)}=2.692, p=0.020, n=13$; paired $t$ test), whereas surface expression of GluN2A was unaffected $\left(t_{(9)}\right.$ $=1.774, p=0.109, n=10$; Fig. $3 c, d)$. Mirroring the GluA1 findings, KN62 significantly blocked the elevation of GluN1 surface expression $\left(0.81 \pm 0.03, t_{(4)}=5.527, p=0.02, n=5\right.$, paired- $t$ test; Fig. $3 e, f)$. GluN1 trafficking was not affected by KT5823 $\left(1.30 \pm 0.05, t_{(4)}=2.541, p=0.130, n=5\right)$, PD98059 $\left(1.13 \pm 0.15, t_{(4)}=3.851, p=0.055, n=5\right.$, paired- $t$ test $)$, or AP5 $\left(1.18 \pm 0.08, t_{(4)}=1.996, p=0.120, n=5\right)$ (Fig. $\left.3 e, f\right)$. The trafficking inhibitor BFA completely blocked the increase in GluN1 surface expression $\left(0.76 \pm 0.03, t_{(4)}=15.13, p=0.0006\right.$, $n=5$; paired- $t$ test; Fig. $3 e, f)$, as did the protein synthesis inhibitor $\operatorname{CHX}\left(0.93 \pm 0.05, t_{(4)}=5.014, p=0.030, n=5\right.$; Fig. $\left.3 e, f\right)$, reminiscent of the effect of CHX on LTP-stimulated NMDAR trafficking in the dentate gyrus in vivo (Williams et al., 2007).

Because electrophysiological studies have shown that $\operatorname{sAPP} \alpha$ administration does not affect either AMPAR-mediated or NMDAR-mediated responses to single-pulse or paired-pulse stimulation (Taylor et al., 2008; see also Fig. $1 a, g$ ), we hypothesized that the glutamate receptor translocation induced by sAPP $\alpha$ must be occurring at extrasynaptic sites. We confirmed this electrophysiologically for NMDARs in patch-clamped CA1 pyramidal cells for which synaptic NMDARs were blocked with the noncompetitive use-dependent NMDAR antagonist MK801 under conditions in which AMPARs, GABARs, and L-type voltagedependent calcium channels were also blocked. Once a full synaptic NMDAR block was achieved and MK801 was washed from the slice, extrasynaptic NMDAR-mediated EPSCs were evoked by single-pulse stimulation in the presence of the glutamate transport inhibitor TBOA and the co-agonist glycine. Under these conditions, NMDAR EPSCs reappeared and increased in magnitude over several minutes as the maximal TBOA bath concentration was achieved. In the presence of $\operatorname{sAPP} \alpha(1 \mathrm{~nm})$ applied continuously from the beginning of MK801 washout, the average NMDAR EPSC peak response recorded once TBOA was fully washed in was significantly greater than that of the vehicle control group (control peak current: $-71.2 \pm 7.0 \mathrm{pA}$; $\operatorname{sAPP} \alpha$ : $-117.7 \pm 18.3 \mathrm{pA} ; t_{(9)}=2.37, p=0.042$; Fig. 4$)$. These findings demonstrate that sAPP $\alpha$ acts to traffic NMDARs into the extrasynaptic membrane, confirming the results of the cell surface protein expression assays above.

\section{BFA and CHX block sAPP $\alpha$ facilitation of LTP}

Given the effectiveness of sAPP $\alpha$ in stimulating receptor trafficking, we investigated whether this contributed to the facilitated induction of LTP. When BFA was administered before and during $\operatorname{sAPP} \alpha$ treatment, there was a decline in baseline responding and the enhancement of the initial induction of LTP (0-5 min) was completely blocked ( $\operatorname{sAPP} \alpha: 72.9 \pm 4.2 \%$; BFA $+\operatorname{sAPP} \alpha$ : $47.3 \pm 5.2 \%$; Fig. $5 a, d)$. In addition, the persistence of LTP as measured $1 \mathrm{~h}$ post-TBS (50-60 $\mathrm{min}$ ) also returned to vehicle control levels, if not below $(\operatorname{sAPP} \alpha: 30.8 \pm 3.3 \%, \mathrm{BFA}+\operatorname{sAPP} \alpha$ : $12.1 \pm 4.0 \%$; cf. Figs. $5 a, d, 1)$, indicating a link between the induction and persistence of the facilitated LTP. Experiments in which BFA (in DMSO) was applied in the absence of TBS showed a small effect on baseline (single pulse) responses, but after washout, there was a complete return to the baseline level $(0.5 \pm 3.9 \%$; Fig. 5ci). Moreover, DMSO by itself had virtually no effect on baseline responses or LTP (Fig. 5cii). Therefore, the block by BFA of LTP enhancement by sAPP $\alpha$ was not due to an effect of the drug alone on basal responses. Consistent with these electrophysiological observations, BFA alone did not affect GluA1 cell surface levels (data not shown), supporting the interpretation that the decline in baseline responding caused by BFA + sAPP $\alpha$ may have been due to a recycling imbalance that enhanced net receptor endocytosis.

Given the protein synthesis dependence of AMPAR and NMDAR trafficking, we tested whether the enhanced LTP persistence was also protein synthesis dependent. CHX completely blocked both the facilitation of the initial induction of LTP and the facilitation of LTP at $1 \mathrm{~h}$ post-TBS ( $\operatorname{sAPP} \alpha+$ CHX: $0-5 \mathrm{~min}$, $36.3 \pm 3.8 \%$; 50-60 min, $15.2 \pm 3.3 \%$; Fig. 5b,d). A second protein synthesis inhibitor, anisomycin $(40 \mu \mathrm{M})$, also had an effect relative to a new interleaved $\operatorname{sAPP} \alpha$ treatment group $(\operatorname{sAPP} \alpha$ : 50-60 min, $50.1 \pm 6.0 \%, n=7 ; \operatorname{sAPP} \alpha+$ Ani: $50-60 \mathrm{~min}$, $22.5 \pm 10.6 \%, n=5 ; p=0.0397$; data not shown). Neither CHX $(-1.3 \pm 1.4 \%$; Fig. $5 c i)$ nor anisomycin $(2.6 \pm 2.2 \%$, data not shown) by themselves exerted any long-term effects on baseline responses. These data support a role for protein-synthesisdependent trafficking of ionotropic glutamate receptors in the facilitation of LTP induction by $\operatorname{sAPP} \alpha$.

Previously, we have shown that, as for $\operatorname{sAPP} \alpha$, an agonist of group $1 \mathrm{mGluRs}$ produces a protein-synthesis-dependent conversion of E-LTP to late-phase LTP (L-LTP) (Raymond et al., 2000). To determine whether the enhancement of LTP by sAPP $\alpha$ acts via mGluRs, we coadministered sAPP $\alpha$ with LY341495 (at $100 \mu \mathrm{M}$, a concentration giving broad-spectrum block of mGluRs). sAPP $\alpha$ was still able to enhance LTP in the presence of LY341495 (45.0 $\pm 4.5 \%, n=8)$ compared with LY341495-only controls $(31.0 \pm 2.9 \%, n=8 ; p=0.042$; Fig. $5 e, f)$.

\section{Metaplasticity effects of sAPP $\alpha$}

Previously, we reported that metabotropic glutamate receptors can prime CA1 synapses for the induction of protein-synthesis- 
a

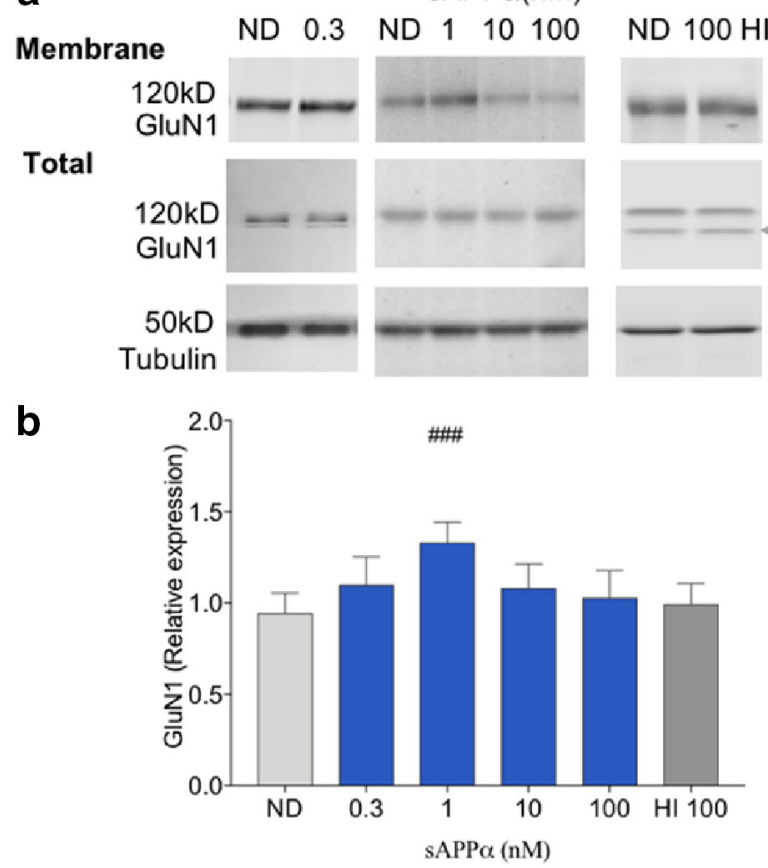

C

Membrane ND 1 ND 1

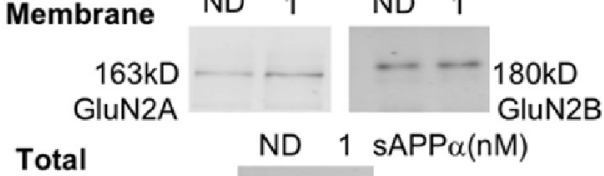

[GluA1]

Total

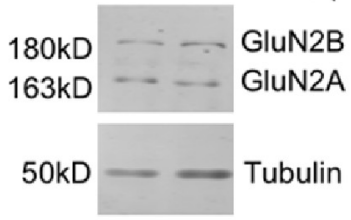

d

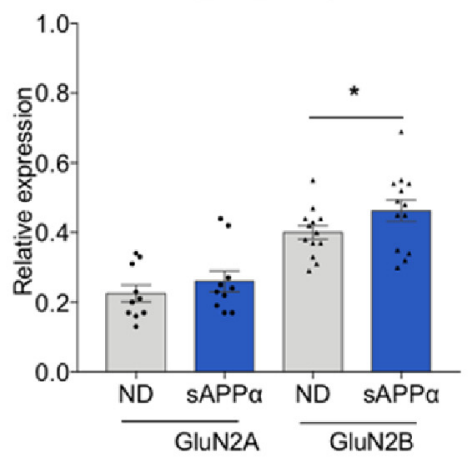

e
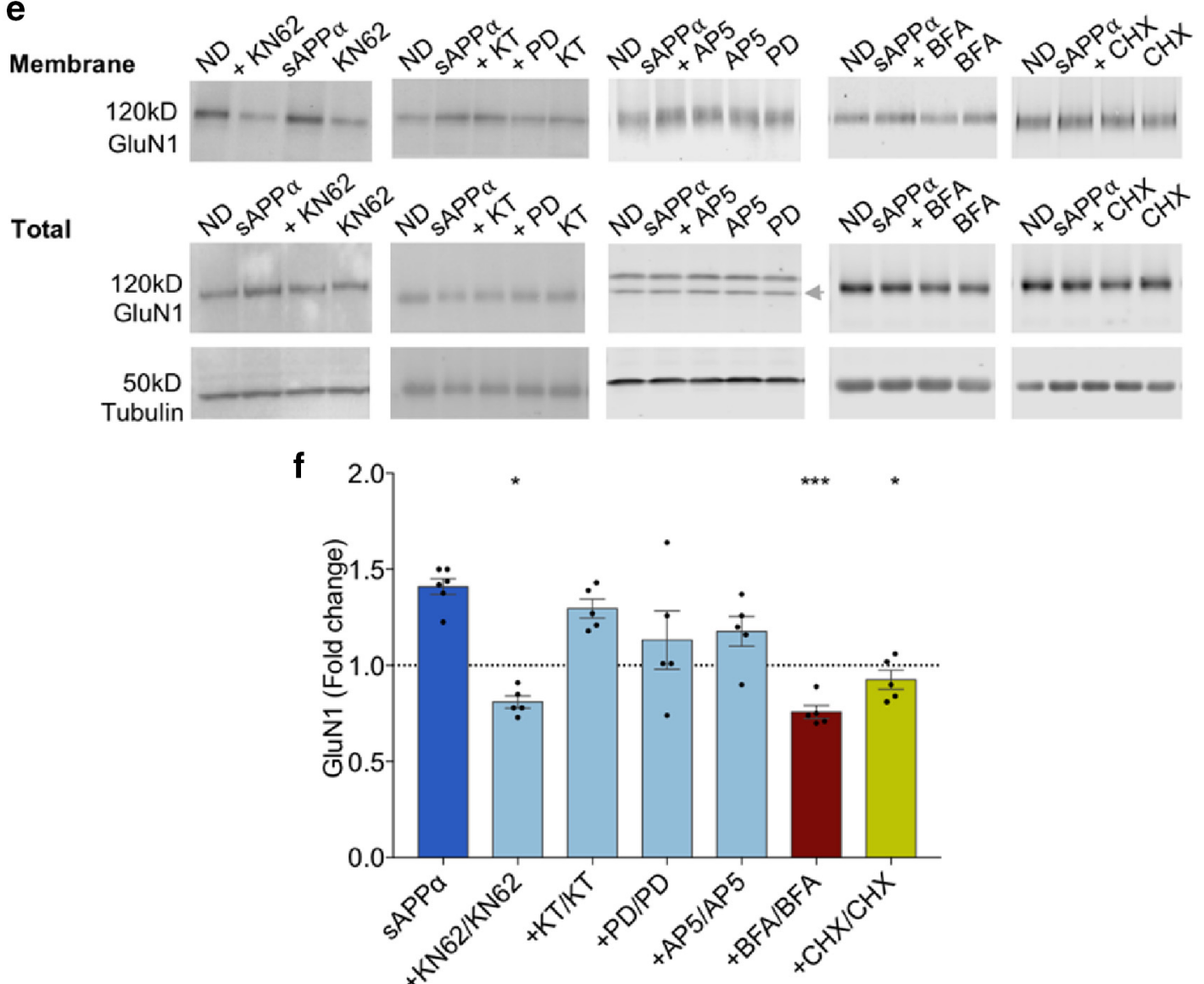

Figure 3. SAPP $\alpha$ treatment increases cell surface expression of GluN1. $\boldsymbol{a}, \boldsymbol{b}, \mathrm{LMM}$ analysis showing that sAPP $\alpha(1 \mathrm{~nm})$ increased cell surface GluN1 levels in a concentration-dependent manner relative to ND controls; $\mathrm{ND}$ control, $n=44$ (9 clusters; litters); $0.3 \mathrm{~nm}, n=5 ; 1 \mathrm{~nm}, n=35$ (8clusters; litters); $10 \mathrm{~nm}, n=10 ; 100 \mathrm{~nm}, n=5 ; 100 \mathrm{~nm}$ HI, $n=4)$. c, d, sAPP $\alpha(1 \mathrm{~nm}$ ) significantly increased surface GluN2B $(n=10)$, but not GluN2A ( $n=13)$ levels. (paired $t$ test). $\boldsymbol{e}, \boldsymbol{f}$, The sAPP $\alpha$-induced increase in cell surface GluN1 was significantly blocked by coincubation with inhibitors of $\mathrm{Ca}^{2+} / \mathrm{CaM}$-dependent kinases (KN62, $10 \mu \mathrm{M}, n=5$ ), trafficking (BFA, $\left.35 \mu \mathrm{M}, n=5\right)$, and protein synthesis (CHX, $\left.60 \mu \mathrm{M}, n=5\right)$, but not significantly by inhibitors of PKG (KT5823, $10 \mu \mathrm{M}, n=$ 5), ERK1/2 (PD98059, $50 \mu \mathrm{M}, n=5$ ) or NMDARs (AP5, $50 \mu \mathrm{m}, n=5$ ). Dashed line shows control level for the ND group (sAPP $\alpha$ ) and the drug-alone groups. Top, Representative Western blots showing either cell surface GluN1, GluN2A, or GluN2B in extracts from hippocampal slices. Data analysis as for Figure 2. For LMM pairwise comparisons (Fisher's LSD), \#\#\#p <0.001; for paired $t$ test (Holm-Bonferroni multiple-comparison correction), ${ }^{*} p<0.05,{ }^{* * *} p<0.001$. 
synaptic MK801
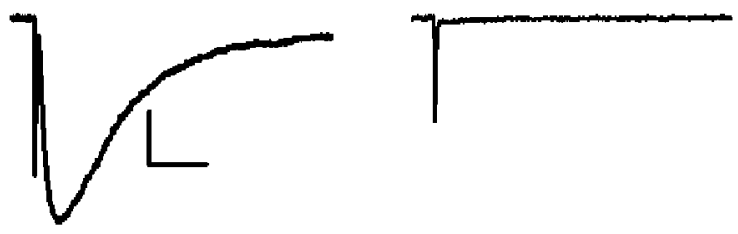

\section{extrasynaptic}

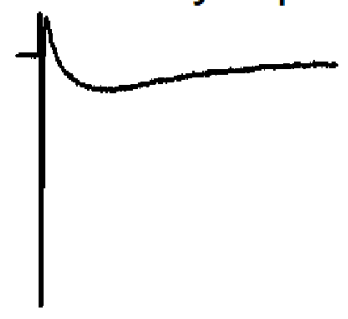

\section{$\operatorname{sAPP} \alpha$}

\section{TBOA + glycine}

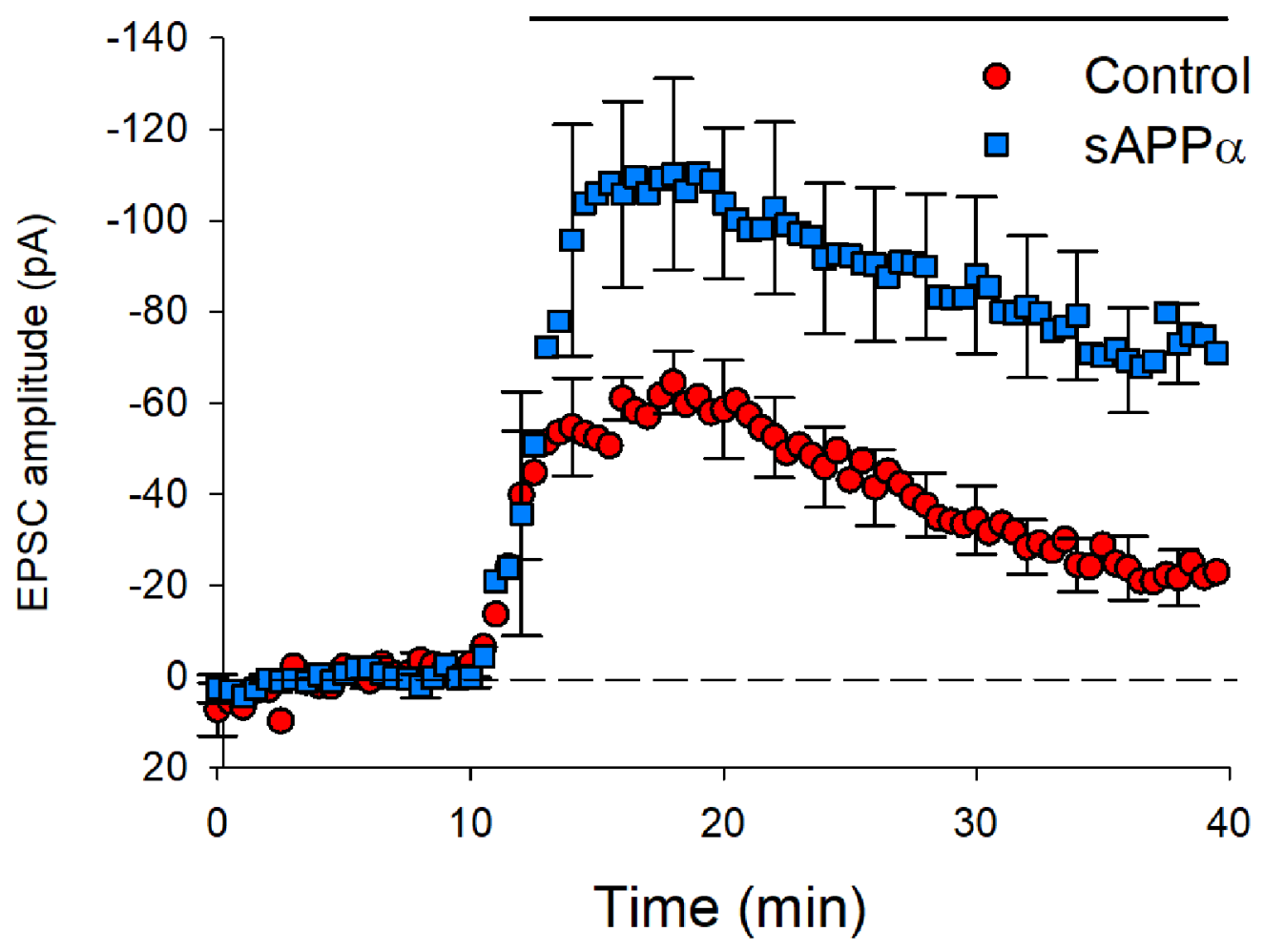

Figure 4. SAPP $\alpha$ increases the extrasynaptic NMDAR complement. Extrasynaptic NMDARs, isolated by blocking synaptic NMDARs with the use-dependent nonreversible blocker MK801 (50 $\mu \mathrm{m}$ ), were activated by single pulses applied to the Schaffer collaterals in the presence of the glutamate transport inhibitor TBOA (50 $\mu \mathrm{M})$ and the co-agonist glycine ( $30 \mu \mathrm{m})$. sAPP $\alpha(1 \mathrm{nM})$ applied for $30 \mathrm{~min}$ before and throughout TBOA/glycine application significantly increased the amplitude of the extrasynaptic EPSCs revealed by TBOA administration compared with nontreated controls (control peak current: $n=6 ; \operatorname{sAPP} \alpha: n=5 ;$ Student's $t$ test, $p=0.042$ ). Note that the synaptic NMDAR currents at the start of the experiment did not differ (control: $1050.2 \mathrm{pA} ; \mathrm{SAPP} \alpha$ : $947.0 \mathrm{pA}$, $p=0.73$ ). Inset, Example NMDAR-mediated EPSCs presented as a 10 trace average for the initial synaptic response (left), the synaptic response after blockade with MK801 (middle), and the extrasynaptic response recorded at the end of the recording period (right). Scale bars, $25 \mathrm{~ms}, 250 \mathrm{pA}$.

dependent LTP (LTP2) (Raymond et al., 2000), consistent with evidence for synaptic tag and capture-based utilization of newly synthesized proteins to promote late-phase LTP (Frey and Morris, 1997). Moreover, stimulation of AMPAR trafficking to extrasynaptic sites can also prime subsequent LTP induction (Sun et al., 2005; Oh et al., 2006). Accordingly, we tested the hypothesis that $\operatorname{sAPP} \alpha$ can prime synapses in a way that enhances later LTP. We bath applied sAPP $\alpha$ as a priming stimulus for $30 \mathrm{~min}$ followed by a washout period of $30 \mathrm{~min}$ before TBS. As for concurrently delivered $\operatorname{sAPP} \alpha$, priming with $\operatorname{sAPP} \alpha$ significantly increased LTP compared with vehicle controls when measured 120 min after TBS (control: $9.0 \pm 2.8 \%$; $\mathrm{sAPP} \alpha: 37.8 \pm 3.6 \%, t_{(16)}$ $=6.48, p<0.001$; Fig. $6 a)$. The facilitation was again observed even in the first 5 min after TBS (control: $44.9 \pm 5.9 \%$; $s$ APP $\alpha$ : $\left.92.5 \pm 9.0 \% ; t_{(16)}=4.58, p=0.0003\right)$ and the enhanced persistence was confirmed by the greater decay time constant of the second, slower negative exponential fitted to the data (control: $66.8 \mathrm{~min} ; \operatorname{sAPP} \alpha$ : $194.9 \mathrm{~min} ; t_{(13)}=1.77, p=0.044$, one-tail $t$ test; Fig. 6a).

To address whether receptor trafficking contributes to the priming of LTP by sAPP $\alpha$, we first tested whether the stimulation of receptor trafficking remained even after $\operatorname{sAPP} \alpha$ was washed out from the slice. Both GluA1 $\left(1.37 \pm 0.08, t_{(5)}=\right.$ 4.716, $p=0.005, n=6$; one-sample $t$ test $)$ and GluN1 (1.41 \pm $\left.0.107, t_{(5)}=6.162, p=0.002, n=6\right)$ showed a continuing enhancement of surface expression relative to vehicle controls 30 min after sAPP $\alpha$ washout (Fig. $6 b, c$ ). When we coincubated BFA and sAPP $\alpha$ and then washed out both drugs for $30 \mathrm{~min}$, the enhancement of surface expression of both subunits was completely blocked and, in fact, compared with $\operatorname{sAPP} \alpha$, expression was significantly decreased (GluA1: $0.78 \pm 0.09, t_{(5)}$ $=5.058, p=0.004, n=6$; paired- $t$ test compared with $\operatorname{sAPP} \alpha$ 
treatment alone; GluN1: $0.86 \pm 0.07$, $t_{(5)}=4.976, p=0.004, n=6$; paired $t$ test; Fig. 6b,c). Similarly, CHX blocked the increase in surface expression of GluA1 $\left(1.04 \pm 0.07, t_{(5)}=3.26, p=\right.$ $0.023, n=6$, paired $t$ test compared with sAPP $\alpha$ treatment alone) as well as GluN1 $\left(1.03 \pm 0.05, t_{(5)}=4.60, p=\right.$ $0.006, n=6$, paired $t$ test).

\section{sAPP $\alpha$ induces cell-wide de novo} synthesis of proteins, including GluA1 To confirm the extent of protein synthesis triggered in cells by $\operatorname{sAPP} \alpha$ and to test whether GluA1 is one of the newly synthesized proteins, we applied FUNCAT-PLA methodology (Hinz et al., 2013; tom Dieck et al., 2015). In control rat hippocampal primary cultures treated only with AHA for $2 \mathrm{~h}$, single-antibody PLA against biotin revealed a punctate fluorescent signal, indicating that newly synthesized proteins were located throughout the soma and along the major dendritic processes, as identified by MAP2 staining (Fig. $7 a, c)$. The protein synthesis inhibitor anisomycin almost completely eliminated the AHA-tagged fluorescent signal $(0.02 \pm 0.005$ relative to control cells; Fig. $7 a, c)$, confirming that the signal arose from de novo protein synthesis. When administered during the AHA treatment, $\operatorname{sAPP} \alpha(1 \mathrm{~nm})$ caused a clear increase $\left(2.0 \pm 0.24, F_{(2,139)}=42.45, p=0.003\right)$ in fluorescence intensity across both the soma and dendrites relative to control cells. Using the FUNCAT-PLA technique (tom Dieck et al., 2015), we showed that one of the upregulated proteins was GluA1. This upregulation occurred more strongly in the dendrites $(3.4 \pm 0.3$-fold, $F_{(2,410)}=56.42, p=2.2651 \mathrm{E}^{-22}$; Fig. $\left.7 e\right)$ than in somata $\left(2.3 \pm 0.3\right.$-fold, $F_{(2,82)}=$ $12.59, p=0.0009)$. GluA2 expression was unchanged (Fig. $7 d, e$ ). This preferential effect of $\operatorname{sAPP} \alpha$ on GluA1 is consistent with the findings reported above from acute hippocampal slices and suggests that, over the longer term, $\operatorname{sAPP} \alpha$ treatment generates a pool of newly synthesized GluA1-containing AMPARs that can be trafficked later to the cell surface.

Given that $\operatorname{sAPP} \alpha$ caused a prolonged increase in the surface expression of AMPARs and NMDARs in a proteinsynthesis-dependent manner, we tested whether these effects contributed to the priming of LTP. Once again, coincubation of the trafficking inhibitor BFA with sAPP $\alpha$ completely blocked the facilitation of LTP measured at $120 \mathrm{~min}$ after TBS (BFA + sAPP $\alpha: 11.3 \pm 6.5 \%)$ compared with sAPP $\alpha$ alone $\left(37.8 \pm 3.6 \%, t_{(15)}=3.43, p=0.004\right.$; Fig. $\left.8 a\right)$. The initial induction of LTP was partially, but not significantly, reduced (Fig. $8 a, c$ ), suggesting that some trafficking was able to occur alone treatment.
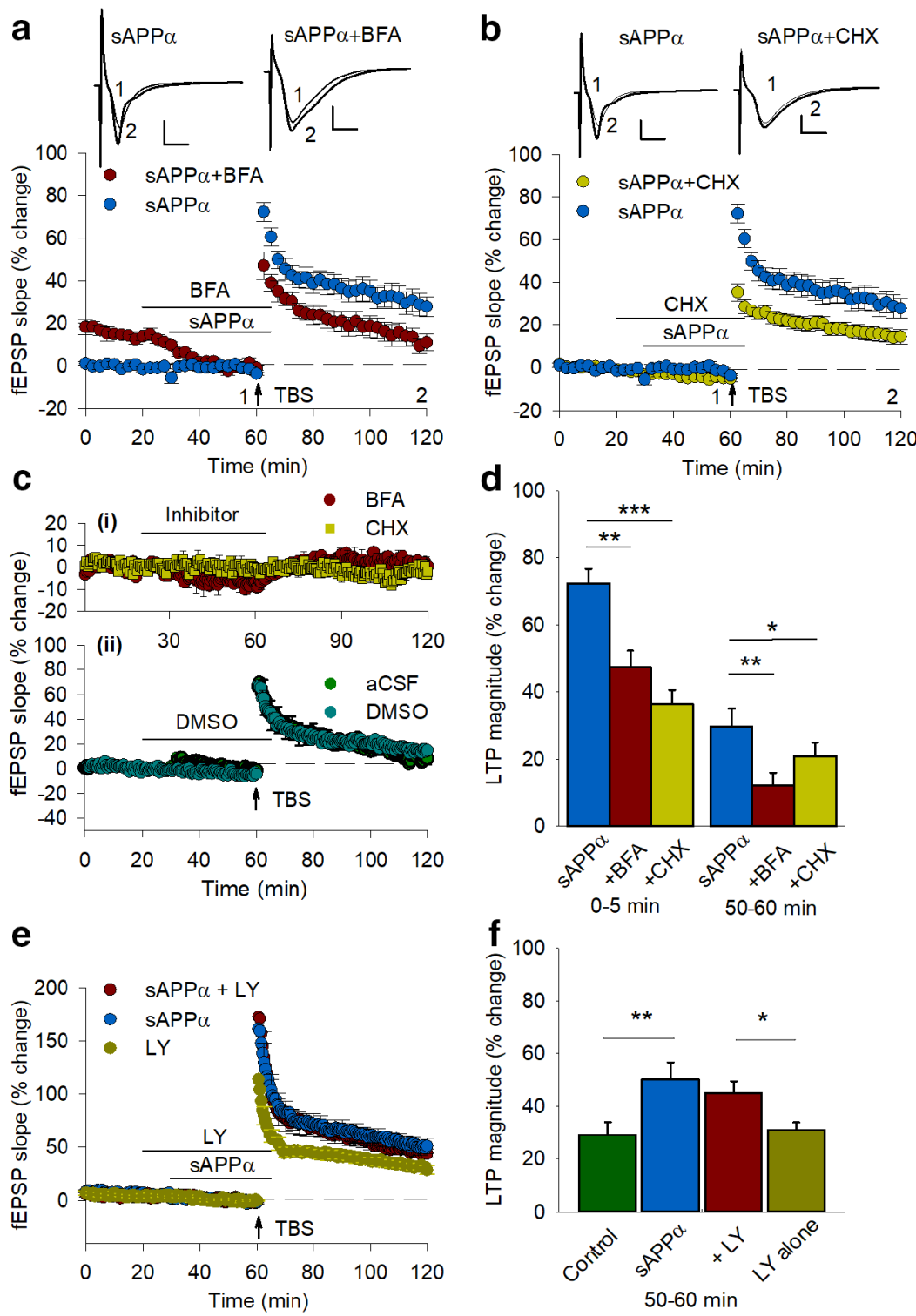

Figure 5. Facilitation of LTP by SAPP $\alpha$ requires protein synthesis and trafficking. $\boldsymbol{a}$, Delivery of the trafficking inhibitor BFA (35 $\mu \mathrm{M})$ beginning $10 \mathrm{~min}$ before SAPP $\alpha(1 \mathrm{~nm})$ perfusion and continuing until SAPP $\alpha$ washout significantly inhibited the initial potentiation ( $0-5$ min after TBS) plus the maintenance of LTP (50-60 min after TBS) compared with sAPP $\alpha$ controls (sAPP $\alpha, n=$ $\left.12 ; \mathrm{BFA}+\operatorname{sAPP} \alpha, n=4 ; 0-5 \mathrm{~min}, t_{(14)}=3.24, p=0.006 ; 50-60 \mathrm{~min}, t_{(14)}=3.03, p=0.009\right)$. $\boldsymbol{b}$, The protein synthesis inhibitor CHX (60 $\mu \mathrm{m}$ ) also blocked both phases of potentiation (sAPP $\alpha+$ CHX: $n=12,0-5$ min, $t_{(22)}=6.45, p=0.00002$; $\left.50-60 \mathrm{~min}, t_{(22)}=3.34, p=0.003\right)$. Inset waveforms are example EPSPs for each group presented as a 10 trace average taken at the end of the baseline (1) and 55- $60 \mathrm{~min}$ after TBS (2). Scale bars, $1 \mathrm{mV}, 5 \mathrm{~ms}$. Arrows indicate the time of TBS delivery. ci, Neither BFA ( $n=5)$ nor CHX ( $n=4)$ alone caused any long-lasting changes in basal synaptic transmission as assessed by fEPSPs. A small response depression occurred during BFA perfusion, but the response recovered back to baseline during the washout period. cii, DMSO did not affect baseline response or the degree of LTP elicited by a TBS (14.5 $\pm 2.8 \%)$ compared with aCSF controls. $\boldsymbol{d}$, Summary histogram showing the level of LTP initial induction (0-5 min) and persistence (50-60 min) after TBS for each group. $e$, The global mGluR antagonist LY341495 (100 $\mu \mathrm{m})$ did not inhibit facilitation of LTP by sAPP $\alpha$. When LY341495 was applied by itself, LTP was similar to controls. $f$, Histogram summarizing the facilitation of LTP by sAPP $\alpha$ in the presence of LY341495. All data are shown as mean percentage change \pm SEM. ${ }^{*} p<0.05,{ }^{* *} p<0.01,{ }^{* * *} p<0.001$ compared with sAPP $\alpha$

before or during the TBS protocol (because BFA had been washed out). In a similar vein, coadministration of $\operatorname{sAPP} \alpha$ with $\mathrm{CHX}$ completely blocked the facilitation of LTP recorded $2 \mathrm{~h}$ after TBS $\left(\mathrm{CHX}+\operatorname{sAPP} \alpha: 12.0 \pm 5.6 \% ; \operatorname{sAPP} \alpha: 37.8 \pm 3.6 \%, t_{(12)}=4.09\right.$, $p=0.002$; Fig. $8 b$ ) because the degree of LTP was not significantly different from nontreated controls $\left(9.0 \pm 2.8 \%, t_{(14)}=0.55, p=\right.$ 0.601). This LTP impairment was evident even at the point of 
a

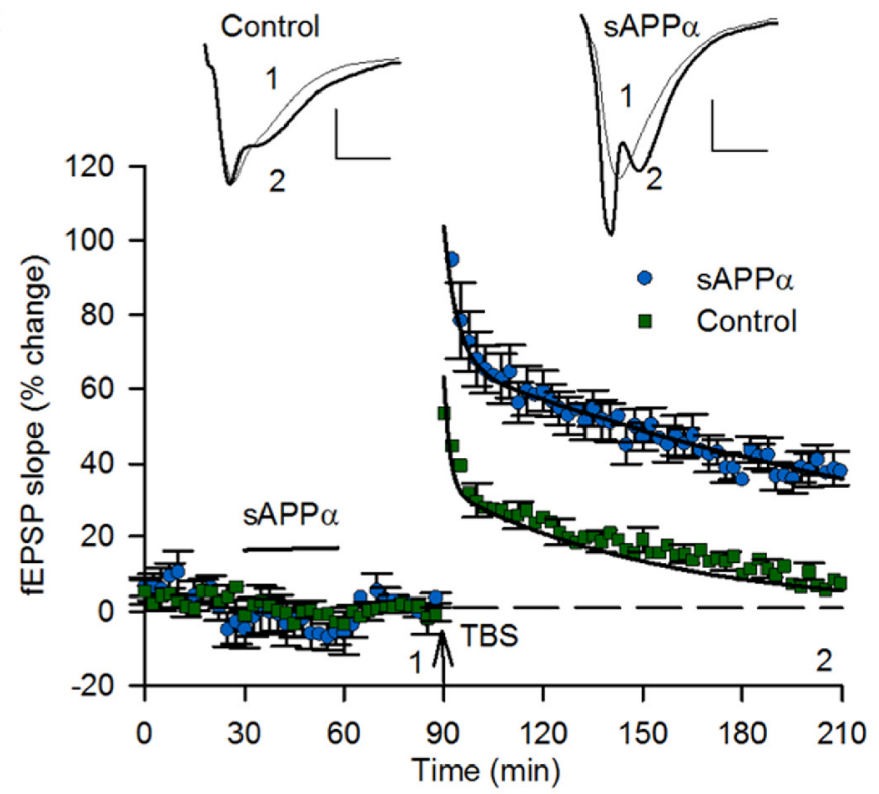

b

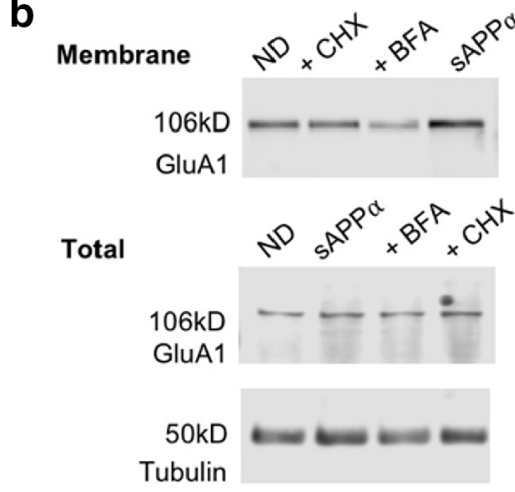

C

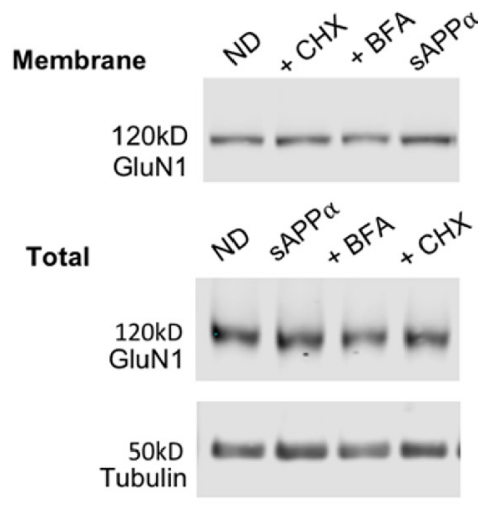

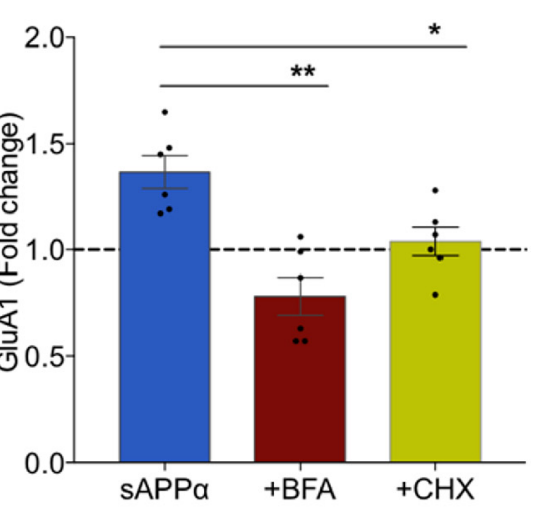

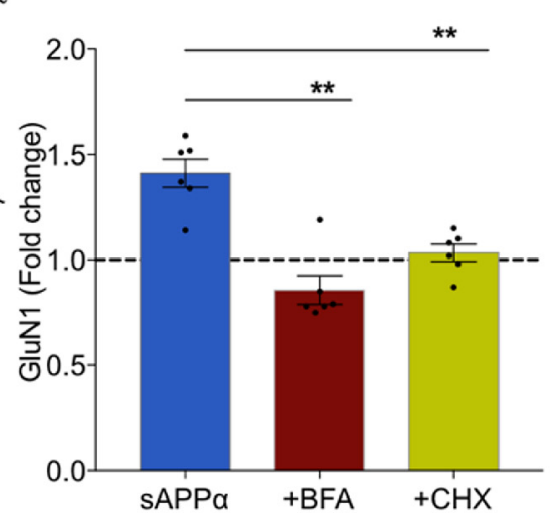

Figure 6. SAPP $\alpha$ promotes stable expression of GluA1- and GluN1-containing receptors at the cell surface and primes LTP. In these experiments, SAPP $\alpha(1 \mathrm{~nm})$ was applied for $30 \mathrm{~min}$ as a priming stimulus and then washed off for a further 30 min before study. $\boldsymbol{a}$, Priming of CA1 neurons with $\operatorname{SAPP} \alpha(n=8)$ significantly facilitated LTP compared with nonprimed controls $(n=10)$ measured $100-120$ min after TBS $\left(t_{(16)}=6.48, p<0.0001\right)$. sAPP $\alpha$ priming also significantly enhanced the post-TBS induction level $\left(0-5 \mathrm{~min}, t_{(16)}=4.60, p=0.0003\right)$. Insets, Example EPSPs for each group presented as a 10 trace average taken at the end of the baseline (1) and 60 min after TBS (2). Scale bars, $1 \mathrm{mV}, 5 \mathrm{~ms}$. Arrow indicates the time of TBS delivery. $\boldsymbol{b}, \boldsymbol{c}$, Slices that were pretreated with $\operatorname{SAPP} \alpha$ as in the LTP experiments but collected for biochemical analysis at the time that TBS would have been delivered showed significantly increased expression of GluA1 and GluN1 at the cell surface. Expression was inhibited by either by BFA $(35 \mu \mathrm{m}, n=6)$ or CHX $(60 \mu \mathrm{m}, n=6)$. Data are expressed as per Figure $2 f$. Significance was assessed using paired $t$ tests (Holm-Bonferroni multiple-comparisons correction), ${ }^{*} p<0.05$, ${ }^{* *} p<0.01$.

initial induction $(\mathrm{CHX}+\operatorname{sAPP} \alpha, 54.5 \pm$ 13.3\%; sAPP $\alpha, 92.5 \pm$ 9.0\%; Fig. 8b,c). These data indicate the sAPP $\alpha$-mediated priming of LTP occurs via coordinated de novo protein synthesis and trafficking of AMPARs and NMDARs to the cell membrane.

\section{Discussion}

sAPP $\alpha$ is well recognized as a potent neuroprotective and neurotrophic signaling molecule, but the mechanisms by which it facilitates memory and LTP have remained enigmatic. Taking advantage of a weak LTP induction paradigm to dissociate phases of LTP (Raymond et al., 2000), we found that a brief application of recombinant $\operatorname{sAPP} \alpha$ converts E-LTP into a protein-synthesis-dependent L-LTP. In contrast, $\operatorname{sAPP} \alpha$ had no significant effect on LTD, indicating specificity for LTP modulation that bears a similarity to the pull-push effects of neuromodulation on LTP/LTD in visual cortex (Huang et al., 2012). The lack of an effect on LTP by $\operatorname{sAPP} \beta$, which lacks sAPP $\alpha$ 's C-terminal $16 \mathrm{aa}$, is consistent with several previous reports (Taylor et al., 2008; Hick et al., 2015; Richter et al., 2018).

It is notable that $\operatorname{sAPP} \alpha$ acted within $30 \mathrm{~min}$ of incubation, consistent with sAPP $\alpha$ 's rapid facilitation of LTP in the dentate gyrus in vivo (Taylor et al., 2008), gene expression in vitro (Ryan et al., 2013), and protein synthesis in synaptoneurosomes (Claasen et al., 2009). Moreover, the effects are similar to those of brain-derived neurotrophic factor (BDNF) and group 1 mGluRs (Raymond et al., 2000; Claasen et al., 2009), suggesting a convergence of protein-synthesisrelated mechanisms activated by these plasticity regulating signaling systems. We have found, however, that sAPP $\alpha$ acts independently of mGluRs, suggesting parallel signal transduction pathways that converge downstream onto protein synthesis mechanisms.

In the present experiments, we confirmed the findings of Claasen et al. (2009) using FUNCAT-PLA methodology and extended them to show that SAPP $\alpha$ treatment not only enhances cell-wide protein synthesis, but also specifically increases the synthesis of GluA1-containing AMPARs. Because inhibition of protein synthesis completely prevented the conversion by SAPP $\alpha$ of E-LTP to L-LTP, the regulation of AMPAR levels may play a crucial role in this process, although the synthesis of other proteins such as trafficking chaperone proteins may also be important. Whether $\operatorname{sAPP} \alpha$ is released endogenously 

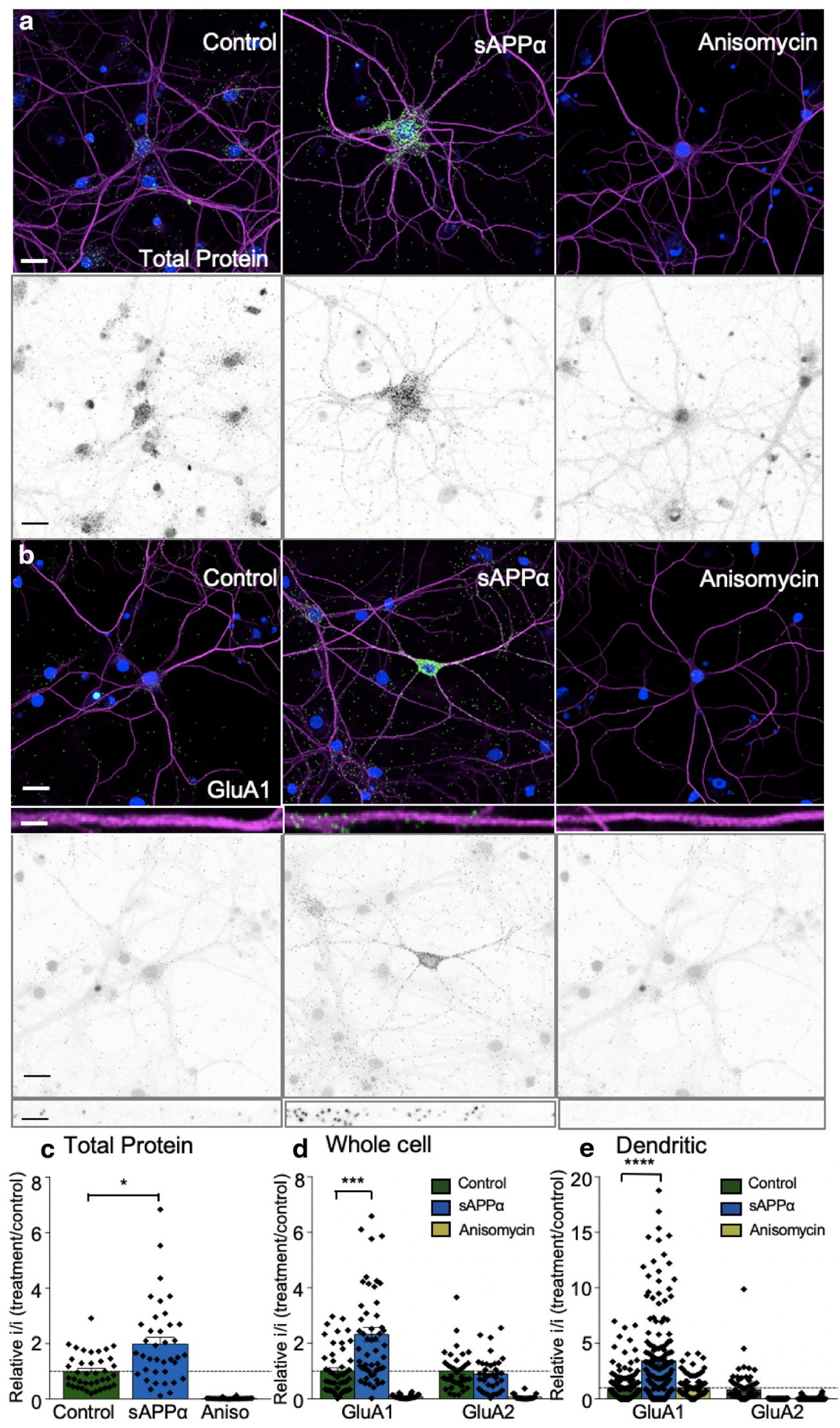

Figure 7. SAPP $\alpha$ stimulates protein synthesis in primary hippocampal neurons. $\boldsymbol{a}$, Representative fluorescence (top) and isolated FUNCAT-PLA signal images (bottom, shown in grayscale) showing detection of single antibody PLA against biotin-labeled newly synthesized proteins under basal conditions (left), with 1 nm sAPP $\alpha$ (middle), or with the protein synthesis inhibitor anisomycin (right). $\boldsymbol{b}$, sAPP $\alpha$ treatment caused an increase in the synthesis of GluA1 subunits. Images of newly synthesized GluA1 protein are shown, as detected via FUNCAT-PLA labeling ( $2 \mathrm{~h}$ AHA, green) basally (left), in response to $1 \mathrm{~nm} \mathrm{SAPP} \alpha$ (middle) or in the presence of anisomycin (right). Representative $50 \mu$ m straightened proximal dendritic segments are illustrated in the inset and isolated FUNCAT-PLA signal is shown in grayscale (bottom). c, Quantification of FUNCAT-PLA signal seen in a normalized to control values (mean \pm SEM from four (Figure legend continues.) 

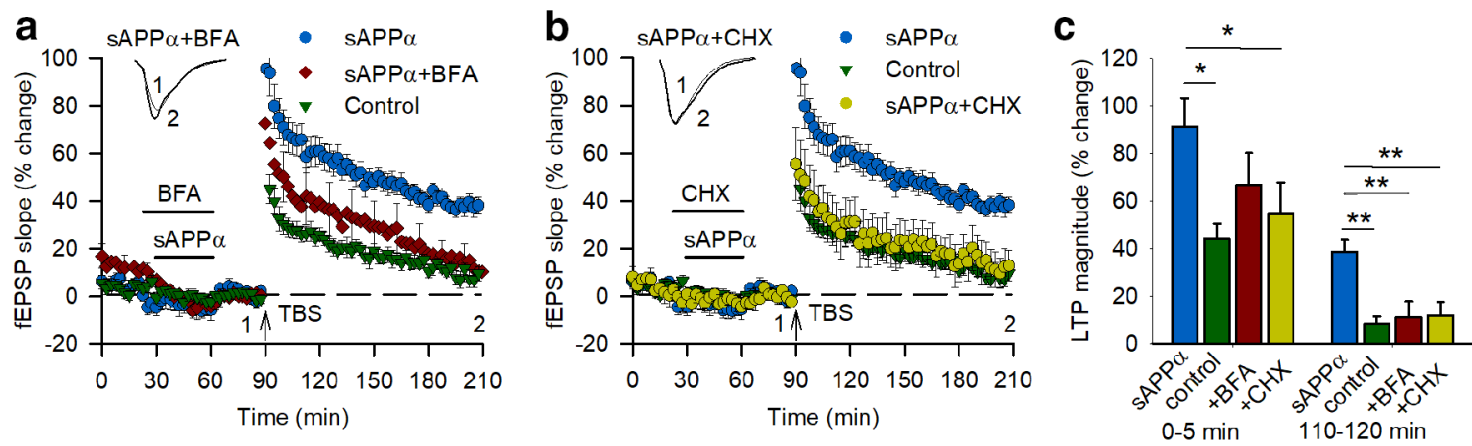

Figure 8. SAPP $\alpha$ priming of LTP is dependent on the synthesis and trafficking of new proteins. $\boldsymbol{a}$, Bath application of BFA $(35 \mu \mathrm{M}, n=9)$ beginning $10 \mathrm{~min}$ before $s$ APP $\alpha$ application and continuing until sAPP $\alpha(1 \mathrm{~nm}, n=8)$ washout prevented the facilitation of LTP observed in response to a TBS delivered 30 min later and measured $2 \mathrm{~h}$ after TBS $(p=0.009)$. The initial induction LTP for the BFA group was not significantly different from the SAPP $\alpha$ or the control group. $\boldsymbol{b}$, Bath application of CHX (60 $\mu \mathrm{M})$ also prevented the facilitation of LTP persistence ( $p=0.009)$ and reduced the initial induction of LTP $(n=6)$ compared with the sAPP $\alpha$ group $(n=8, p=0.022)$. c, Summary histogram showing the facilitation of LTP by sAPP $\alpha$ and the inhibition of the effect by both BFA and CHX. All data are shown as mean percentage change \pm SEM. Dunnett's post hoc tests, ${ }^{*} p<0.05,{ }^{* *} p<0.01$ compared with SAPP $\alpha$ alone treatment. Waveforms in $\boldsymbol{a}$ and $\boldsymbol{b}$ are as in previous figures. These data, in combination with the receptor subunit trafficking data, indicate that the priming mechanism of sAPP $\alpha$ involved a coordinated enhancement of protein synthesis and trafficking of glutamate receptors to the cell membrane.

during TBS and contributes to the processes underlying LTP facilitation is unknown. However, given that the $\alpha$-secretase inhibitor impairs LTP induction and maintenance (Taylor et al., 2008), it is reasonable to assume that endogenously released sAPP $\alpha$ in the present experiments could be acting in concert with the exogenously provided protein. Conversely, $\operatorname{sAPP} \alpha$ is able to facilitate LTP even when APP is knocked out (Hick et al., 2015), indicating that endogenous $\operatorname{sAPP} \alpha$ is not essential for the exogenous protein's actions. Recent work suggests that $\operatorname{sAPP} \alpha$ may promote LTP by acting as a positive allosteric modulator at $\alpha 7$ nicotinic receptors (Richter et al., 2018). By promoting postsynaptic calcium influx, these receptors might contribute to the activation of plasticity-associated processes such as receptor trafficking and protein synthesis.

It is interesting that the facilitation of LTP by $\operatorname{sAPP} \alpha$ was evident immediately after tetanization (Fig. 1) (Taylor et al., 2008; Hick et al., 2015), suggesting an engagement of mechanisms additional to the conventional contributions of de novo protein synthesis to L-LTP. The fact that cell surface accumulation of both AMPAR and NMDAR subtypes required de novo protein synthesis suggests a novel important role for protein synthesis in even the earliest phase of LTP. Because the sAPP $\alpha$ mediated receptor accumulation was also blocked by BFA for both subtypes, we interpret the receptor accumulation as being due to enhanced trafficking to the membrane. Moreover, the fact

$\leftarrow$

(Figure legend continued.) experiments, $n=39$ control cells, $n=38$ sAPP $\alpha$ cells, or $n=26$ anisomycin cells. SAPP $\alpha$ treatment significantly enhanced global protein synthesis $(p<0.05)$. Note that there was no difference in neuronal size between groups (data not shown). $\boldsymbol{d}$, Wholecell quantification of GluA1 and GluA2 FUNCAT-PLA signals for SAPP $\alpha$ - and anisomycin-treated cells normalized to control neurons (mean \pm SEM from four experiments, $n=48 \mathrm{GluA} 1$ control cells, $n=55 \mathrm{sAPP} \alpha$ cells, and $n=28$ anisomycin cells; GluAz: $n=37$ control cells, $n=26$ sAPP $\alpha$ cells, and $n=18$ anisomycin cells). Treatment with sAPP $\alpha$ caused a significant increase in GluA1 synthesis $(p<0.001)$, but had no significant effect on GluA2 synthesis. $\boldsymbol{e}$, Analysis of the dendritic signal represented as inset images in $\boldsymbol{b}$. When normalized to control, SAPP $\alpha$ treatment significantly increased the FUNCAT-PLA-detected level of newly made GluA1 expressed in the dendrites $(p<0.0001)$, with no effect on GluA2 [mean \pm SEM from four experiments, $n=168$ dendrites (GluA1 control), $n=177$ dendrites (sAPP $\alpha$ ), and $n=68$ dendrites (anisomycin); GluAz: $n=91$ dendrites (control), $n=87$ dendrites (sAPP $\alpha$ ), and $n=$ 35 dendrites (anisomycin)]. Green, PLA signal; magenta, MAP2; blue, DAPI-labeled nuclei; grayscale images, isolated FUNCAT-PLA signal. FUNCAT-PLA signal dilated used ImageJ for visualization. Scale bars on main images, $30 \mu \mathrm{m}$; on inset images, $5 \mu \mathrm{m}$. Statistics were calculated on raw values using ANOVA and Kruskal-Wallis tests. ${ }^{*} p<0.05,{ }^{* * *} p<0.001,{ }^{* * * *} p<0.0001$. that electrophysiological recordings have shown no direct effects of sAPP $\alpha$ on single shock AMPAR- or NMDAR-mediated responses (Taylor et al., 2008) (Fig. 1) suggests that the receptor trafficking occurs to extrasynaptic sites, confirmed electrophysiologically at least for NMDARs. Such extrasynaptic trafficking of AMPARs has been shown to be important for LTP induction because it is these receptors that move to the postsynaptic density to mediate postsynaptic expression of LTP. However, NMDARs at extrasynaptic sites may also contribute to LTP induction when high-frequency stimulation releases glutamate in sufficient concentration to escape the synaptic cleft and activate those receptors (Taylor et al., 2008).

Our data support the hypothesis that $\operatorname{sAP} \alpha$ initially enhances LTP via increasing glutamate receptor trafficking rather than effecting diffusional trapping of receptors or the new synthesis of receptor subunits. First, no increase in the cell-wide levels of receptor subunits was detected following $30 \mathrm{~min}$ exposure to sAPPa (Figs. 2,3) despite an increase in cell surface expression of GluA1 and GluN1/GluN2B receptors. Second, both the enhanced LTP and the associated enhanced cell surface levels of GluA1 and GluN1 were completely blocked by BFA, which is known to block export from proteins from the Golgi (Misumi et al., 1986) and to cause morphological changes in endosomes (Klausner et al., 1992) that are associated with AMPAR trafficking (Park et al., 2004). Third, the enhanced trafficking of GluA1, but not GluA2, subunits is consistent with the role of GluA1only-containing AMPARs in the early postsynaptic expression of LTP (Hayashi et al., 2000; Plant et al., 2006; Williams et al., 2007; Park et al., 2016), as well as with GluA1 subunits being primarily synthesized within the soma and transported to dendrites, where they enter recycling endosomes that move to the surface membrane in response to stimulation (Anggono and Huganir, 2012).

The increased trafficking of GluAl was associated with a CaMKII-mediated enhancement of Ser831phosphorylation, another hallmark of GluA1 trafficking (Hayashi et al., 2000), and was blocked by KN62. This is in agreement with the trafficking of AMPARs in C. elegans being dependent on UNC-43 activity, the homolog of mammalian CaMKII (Hoerndli et al., 2015). Because KN62 also blocked trafficking of NMDARs, the KN62 effect could be indirect through reduced phosphorylation of other proteins such as rasGAP (Zhu et al., 2002) or chaperone proteins. Interestingly, the canonical PKA p-Ser845 site on GluA1, also targeted by PKG (Serulle et al., 2007), was not altered by $\operatorname{sAPP} \alpha$ 
treatment even though this residue has been considered an important requirement for AMPAR trafficking (Sun et al., 2005; Oh et al., 2006) and stabilization of GluA1-only-containing AMPARs at perisynaptic sites (He et al., 2009). This may reflect that the basal level of Ser845 phosphorylation was already sufficient for $\operatorname{sAPP} \alpha$ to exert its effects. Trafficking of GluA1 was, however, blocked by a PKG inhibitor. Because we have shown that both a PKG inhibitor and KN62 block sAPP $\alpha$-stimulated protein synthesis (Claasen et al., 2009), activation of these molecules may stimulate the local synthesis of accessory proteins that are critical to the enhanced surface accumulation of the receptor. These results emphasize the multiple transduction signals mediating the effects of sAPP $\alpha$ (Barger et al., 1995; Furukawa et al., 1996).

\section{sAPP $\alpha$ and metaplasticity}

The increase in surface expression of glutamate receptors that was still evident $30 \mathrm{~min}$ after $\operatorname{sAPP} \alpha$ washout suggests that a persistent state of LTP readiness had been established. Indeed, LTP was as efficiently enhanced $30 \mathrm{~min}$ after $\operatorname{sAPP} \alpha$ washout as during its presence, with the same mechanisms involved. The finding that $\mathrm{CHX}$ blocked the $\operatorname{sAPP} \alpha$-mediated facilitation of LTP at its very earliest stages in both this experiment and when sAPP $\alpha$ was delivered concurrently with TBS was surprising given that protein synthesis inhibitors traditionally only affect L-LTP (Krug et al., 1984; Frey et al., 1988; Otani et al., 1989). However, our demonstration that $\operatorname{sAPP} \alpha$ stimulates accumulation of AMPARs and NMDARs at extrasynaptic sites in a proteinsynthesis-dependent manner offers a new insight into the way in which de novo protein synthesis can regulate the priming of induction phases of LTP. These results are consistent with other studies suggesting that constitutive protein synthesis before LTP induction may be an important mechanism supporting L-LTP (Abbas et al., 2009; Abbas, 2013), as well as the possibility that calcium-permeable GluA1 homomeric receptors contribute to the activation of de novo protein synthesis (Park et al., 2016). Because we have shown that $\operatorname{sAPP} \alpha$ has a cell-wide effect on de novo protein synthesis, enhancement of the synthesis of proteins additional to the glutamate receptors are likely to contribute to sAPP $\alpha$-induced priming and a proteomic analysis to identify these proteins would be informative.

\section{Conclusions}

sAPP $\alpha$ has many of the hallmark functionalities of neurotrophins, being not only neurotrophic in promoting neurite outgrowth, axonal expansion, synaptogenesis, and neurogenesis, but also neuroprotective against a wide range of toxic insults (Turner et al., 2003; Chasseigneaux and Allinquant, 2012; Kögel et al., 2012). Moreover, although $\operatorname{sAPP} \alpha$ and $\mathrm{A} \beta$ are generated in different cell compartments, sAPP $\alpha$ can directly inhibit the activation of the $\beta$-secretase that is crucial for $\mathrm{A} \beta$ production (Obregon et al., 2012). However, like neurotrophins, $\operatorname{sAPP} \alpha$ also enhances LTP and thus plays a wider role in normal adult functions such as learning and memory. Unlike BDNF (Kang and Schuman, 1995; Messaoudi et al., 1998), however, sAPP $\alpha$ does not by itself cause synaptic potentiation even though it is a potent stimulator of protein synthesis. Rather, it engages metaplasticity mechanisms (Abraham, 2008), specifically a coordinated de novo protein synthesis and glutamate receptor trafficking that puts synapses in a state of readiness for future LTP and, presumably, learning.

\section{References}

Abbas AK (2013) Evidence for constitutive protein synthesis in hippocampal LTP stabilization. Neuroscience 246:301-311.
Abbas AK, Dozmorov M, Li R, Huang FS, Hellberg F, Danielson J, Tian Y, Ekström J, Sandberg M, Wigström H (2009) Persistent LTP without triggered protein synthesis. Neurosci Res 63:59-65.

Abraham WC (2008) Metaplasticity: tuning synapses and networks for plasticity. Nat Rev Neurosci 9:387.

Anggono V, Huganir RL (2012) Regulation of AMPA receptor trafficking and synaptic plasticity. Curr Opin Neurobiol 22:461-469.

Baratchi S, Evans J, Tate WP, Abraham WC, Connor B (2012) Secreted amyloid precursor proteins promote proliferation and glial differentiation of adult hippocampal neural progenitor cells. Hippocampus 22:1517-1527.

Barger SW, Fiscus RR, Ruth P, Hofmann F, Mattson MP (1995) Role of cyclic GMP in the regulation of neuronal calcium and survival by secreted forms of beta-amyloid precursor. J Neurochem 64:2087-2096.

Bourdet I, Preat T, Goguel V (2015) The full-length form of the drosophila amyloid precursor protein is involved in memory formation. J Neurosci 35:1043-1051.

Chasseigneaux S, Allinquant B (2012) Functions of abeta, sAPPalpha and sAPPbeta: similarities and differences. J Neurochem 120:99-108.

Chasseigneaux S, Dinc L, Rose C, Chabret C, Coulpier F, Topilko P, Mauger G, Allinquant B (2011) Secreted amyloid precursor protein beta and secreted amyloid precursor protein alpha induce axon outgrowth in vitro through Egr1 signaling pathway. PLoS One 6:e16301.

Claasen AM, Guévremont D, Mason-Parker SE, Bourne K, Tate WP, Abraham WC, Williams JM (2009) Secreted amyloid precursor proteinalpha upregulates synaptic protein synthesis by a protein kinase G-dependent mechanism. Neurosci Lett 460:92-96.

Copanaki E, Chang S, Vlachos A, Tschäpe JA, Müller UC, Kögel D, Deller T (2010) sAPPalpha antagonizes dendritic degeneration and neuron death triggered by proteasomal stress. Mol Cell Neurosci 44:386-393.

Fol R, Braudeau J, Ludewig S, Abel T, Weyer SW, Roederer JP, Brod F, Audrain M, Bemelmans AP, Buchholz CJ, Korte M, Cartier N, Müller UC (2016) Viral gene transfer of APPsalpha rescues synaptic failure in an Alzheimer's disease mouse model. Acta Neuropathol 131:247-266.

Frey U, Morris RG (1997) Synaptic tagging and long-term potentiation. Nature 385:533-536.

Frey U, Krug M, Reymann KG, Matthies H (1988) Anisomycin, an inhibitor of protein synthesis, blocks late phases of LTP phenomena in the hippocampal CA1 region in vitro. Brain Res 452:57-65.

Frey U, Frey S, Schollmeier F, Krug M (1996) Influence of actinomycin D, a RNA synthesis inhibitor, on long-term potentiation in rat hippocampal neurons in vivo and in vitro. J Physiol 490:703-711.

Furukawa K, Mattson MP (1998) Secreted amyloid precursor protein alpha selectively suppresses $\mathrm{N}$-methyl-D-aspartate currents in hippocampal neurons: involvement of cyclic GMP. Neuroscience 83:429-438.

Furukawa K, Barger SW, Blalock EM, Mattson MP (1996) Activation of K+ channels and suppression of neuronal activity by secreted beta-amyloidprecursor protein. Nature 379:74-78.

Hayashi Y, Shi SH, Esteban JA, Piccini A, Poncer JC, Malinow R (2000) Driving AMPA receptors into synapses by LTP and CaMKII: requirement for GluR1 and PDZ domain interaction. Science 287:2262-2267.

He K, Song L, Cummings LW, Goldman J, Huganir RL, Lee HK (2009) Stabilization of Ca2+-permeable AMPA receptors at perisynaptic sites by GluR1-S845 phosphorylation. Proc Natl Acad Sci U S A 106:2003320038.

Hick M, Herrmann U, Weyer SW, Mallm JP, Tschäpe JA, Borgers M, Mercken M, Roth FC, Draguhn A, Slomianka L, Wolfer DP, Korte M, Müller UC (2015) Acute function of secreted amyloid precursor protein fragment APPsalpha in synaptic plasticity. Acta Neuropathol 129:21-37.

Hinz FI, Dieterich DC, Schuman EM (2013) Teaching old NCATs new tricks: using non-canonical amino acid tagging to study neuronal plasticity. Curr Opin Chem Biol 17:738-746.

Hoerndli FJ, Wang R, Mellem JE, Kallarackal A, Brockie PJ, Thacker C, Madsen DM, Maricq AV (2015) Neuronal activity and CaMKII regulate kinesin-mediated transport of synaptic AMPARs. Neuron 86:457-474.

Huang S, Treviño M, He K, Ardiles A, Pasquale Rd, Guo Y, Palacios A, Huganir R, Kirkwood A (2012) Pull-push neuromodulation of LTP and LTD enables bidirectional experience-induced synaptic scaling in visual cortex. Neuron 73:497-510.

Ishida A, Furukawa K, Keller JN, Mattson MP (1997) Secreted form of betaamyloid precursor protein shifts the frequency dependency for induction 
of LTD, and enhances LTP in hippocampal slices. Neuroreport 8:2133-2137.

Kang H, Schuman EM (1995) Long-lasting neurotrophin-induced enhancement of synaptic transmission in the adult hippocampus. Science 267:1658-1662.

Klausner RD, Donaldson JG, Lippincott-Schwartz J (1992) Brefeldin A: insights into the control of membrane traffic and organelle structure. J Cell Biol 116:1071-1080.

Kögel D, Deller T, Behl C (2012) Roles of amyloid precursor protein family members in neuroprotection, stress signaling and aging. Exp Brain Res 217:471-479.

Krug M, Lössner B, Ott T (1984) Anisomycin blocks the late phase of longterm potentiation in the dentate gyrus of freely moving rats. Brain Res Bull 13:39-42.

Mattson MP, Cheng B, Culwell AR, Esch FS, Lieberburg I, Rydel RE (1993) Evidence for excitoprotective and intraneuronal calcium-regulating roles for secreted forms of the beta-amyloid precursor protein. Neuron $10: 243-254$

Messaoudi E, Bârdsen K, Srebro B, Bramham CR (1998) Acute intrahippocampal infusion of BDNF induces lasting potentiation of synaptic transmission in the rat dentate gyrus. J Neurophysiol 79:496-499.

Meziane H, Dodart JC, Mathis C, Little S, Clemens J, Paul SM, Ungerer A (1998) Memory-enhancing effects of secreted forms of the beta-amyloid precursor protein in normal and amnestic mice. Proc Natl Acad Sci U S A 95:12683-12688.

Mileusnic R, Lancashire CL, Rose SP (2004) The peptide sequence arg-gluarg, present in the amyloid precursor protein, protects against memory loss caused by A beta and acts as a cognitive enhancer. Eur J Neurosci 19:1933-1938.

Misumi Y, Misumi Y, Miki K, Takatsuki A, Tamura G, Ikehara Y (1986) Novel blockade by brefeldin A of intracellular transport of secretory proteins in cultured rat hepatocytes. J Biol Chem 261:11398-11403.

Mockett BG, Brooks WM, Tate WP, Abraham WC (2004) Dopamine D1/D5 receptor activation fails to initiate an activity-independent latephase LTP in rat hippocampus. Brain Res 1021:92-100.

Mockett BG, Guévremont D, Williams JM, Abraham WC (2007) Dopamine D1/D5 receptor activation reverses NMDA receptor-dependent longterm depression in rat hippocampus. J Neurosci 27:2918-2926.

Mockett BG, Guévremont D, Wutte M, Hulme SR, Williams JM, Abraham WC (2011) Calcium/calmodulin-dependent protein kinase II mediates group I metabotropic glutamate receptor-dependent protein synthesis and long-term depression in rat hippocampus. J Neurosci 31:7380-7391.

Mockett BG, Richter M, Abraham WC, Müller UC (2017) Therapeutic potential of secreted amyloid precursor protein APPsalpha. Front Mol Neurosci 10:30.

Mockett B, Coussens C, Abraham WC (2002) NMDA receptor-mediated metaplasticity during the induction of long-term depression by lowfrequency stimulation. Eur J Neurosci 15:1819-1826.

Moreno L, Rose C, Mohanraj A, Allinquant B, Billard JM, Dutar P (2015) sAbetaPPalpha improves hippocampal NMDA-dependent functional alterations linked to healthy aging. J Alzheimers Dis 48:927-935.

Nguyen PV, Abel T, Kandel ER (1994) Requirement of a critical period of transcription for induction of a late phase of LTP. Science 265:1104-1107.

Obregon D, Hou H, Deng J, Giunta B, Tian J, Darlington D, Shahaduzzaman M, Zhu Y, Mori T, Mattson MP, Tan J (2012) Soluble amyloid precursor protein-alpha modulates beta-secretase activity and amyloid-beta generation. Nat Commun 3:777.

Oh MC, Derkach VA, Guire ES, Soderling TR (2006) Extrasynaptic membrane trafficking regulated by GluR1 serine 845 phosphorylation primes AMPA receptors for long-term potentiation. J Biol Chem 281:752-758.

Otani S, Marshall CJ, Tate WP, Goddard GV, Abraham WC (1989) Maintenance of long-term potentiation in rat dentate gyrus requires protein synthesis but not messenger RNA synthesis immediately posttetanization. Neuroscience 28:519-526.

Park M, Penick EC, Edwards JG, Kauer JA, Ehlers MD (2004) Recycling endosomes supply AMPA receptors for LTP. Science 305:1972-1975.

Park P, Sanderson TM, Amici M, Choi SL, Bortolotto ZA, Zhuo M, Kaang BK, Collingridge GL (2016) Calcium-permeable AMPA receptors mediate the induction of the protein kinase A-dependent component of long-term potentiation in the hippocampus. J Neurosci 36:622-631.
Plant K, Pelkey KA, Bortolotto ZA, Morita D, Terashima A, McBain CJ, Collingridge GL, Isaac JT (2006) Transient incorporation of native GluR2-lacking AMPA receptors during hippocampal long-term potentiation. Nat Neurosci 9:602-604.

Raymond CR, Thompson VL, Tate WP, Abraham WC (2000) Metabotropic glutamate receptors trigger homosynaptic protein synthesis to prolong long-term potentiation. J Neurosci 20:969-976.

Richter MC, Ludewig S, Winschel A, Abel T, Bold C, Salzburger LR, Klein S, Han K, Weyer SW, Fritz AK, Laube B, Wolfer DP, Buchholz CJ, Korte M, Müller UC (2018) Distinct in vivo roles of secreted APP ectodomain variants APPsalpha and APPsbeta in regulation of spine density, synaptic plasticity, and cognition. EMBO J 37:e98335.

Ring S, Weyer SW, Kilian SB, Waldron E, Pietrzik CU, Filippov MA, Herms J, Buchholz C, Eckman CB, Korte M, Wolfer DP, Müller UC (2007) The secreted beta-amyloid precursor protein ectodomain APPs alpha is sufficient to rescue the anatomical, behavioral, and electrophysiological abnormalities of APP-deficient mice. J Neurosci 27:7817-7826.

Roch JM, Masliah E, Roch-Levecq AC, Sundsmo MP, Otero DA, Veinbergs I, Saitoh T (1994) Increase of synaptic density and memory retention by a peptide representing the trophic domain of the amyloid beta/A4 protein precursor. Proc Natl Acad Sci U S A 91:7450-7454.

Ryan MM, Morris GP, Mockett BG, Bourne K, Abraham WC, Tate WP, Williams JM (2013) Time-dependent changes in gene expression induced by secreted amyloid precursor protein-alpha in the rat hippocampus. BMC Genomics 14:376.

Serulle Y, Zhang S, Ninan I, Puzzo D, McCarthy M, Khatri L, Arancio O, Ziff EB (2007) A GluR1-cGKII interaction regulates AMPA receptor trafficking. Neuron 56:670-688.

Shi SH, Hayashi Y, Petralia RS, Zaman SH, Wenthold RJ, Svoboda K, Malinow R (1999) Rapid spine delivery and redistribution of AMPA receptors after synaptic NMDA receptor activation. Science 284:1811-1816.

Sun X, Zhao Y, Wolf ME (2005) Dopamine receptor stimulation modulates AMPA receptor synaptic insertion in prefrontal cortex neurons. J Neurosci 25:7342-7351.

Tan VTY, Mockett BG, Ohline SM, Parfitt KD, Wicky HE, Peppercorn K, Schoderboeck L, Yahaya MFB, Tate WP, Hughes SM, Abraham WC (2018) Lentivirus-mediated expression of human secreted amyloid precursor protein-alpha prevents development of memory and plasticity deficits in a mouse model of Alzheimer's disease. Mol Brain 11:7.

Taylor CJ, Ireland DR, Ballagh I, Bourne K, Marechal NM, Turner PR, Bilkey DK, Tate WP, Abraham WC (2008) Endogenous secreted amyloid precursor protein-alpha regulates hippocampal NMDA receptor function, long-term potentiation and spatial memory. Neurobiol Dis 31:250-260. tom Dieck S, Kochen L, Hanus C, Heumüller M, Bartnik I, Nassim-Assir B, Merk K, Mosler T, Garg S, Bunse S, Tirrell DA, Schuman EM (2015) Direct visualization of newly synthesized target proteins in situ. Nat Methods 12:411-414.

Turner PR, O'Connor K, Tate WP, Abraham WC (2003) Roles of amyloid precursor protein and its fragments in regulating neural activity, plasticity and memory. Prog Neurobiol 70:1-32.

Turner PR, Bourne K, Garama D, Carne A, Abraham WC, Tate WP (2007) Production, purification and functional validation of human secreted amyloid precursor proteins for use as neuropharmacological reagents. J Neurosci Methods 164:68-74.

Williams JM, Mason-Parker SE, Abraham WC, Tate WP (1998) Biphasic changes in the levels of N-methyl-D-aspartate receptor-2 subunits correlate with the induction and persistence of long-term potentiation. Brain Res Mol Brain Res 60:21-27.

Williams JM, Guévremont D, Kennard JT, Mason-Parker SE, Tate WP, Abraham WC (2003) Long-term regulation of N-methyl-D-aspartate receptor subunits and associated synaptic proteins following hippocampal synaptic plasticity. Neuroscience 118:1003-1013.

Williams JM, Guévremont D, Mason-Parker SE, Luxmanan C, Tate WP, Abraham WC (2007) Differential trafficking of AMPA and NMDA receptors during long-term potentiation in awake adult animals. J Neurosci 27:14171-14178.

Zhu JJ, Qin Y, Zhao M, Van Aelst L, Malinow R (2002) Ras and rap control AMPA receptor trafficking during synaptic plasticity. Cell 110:443-455. 